University of Rhode Island

DigitalCommons@URI

Open Access Master's Theses

1975

\title{
Goal-Directed Fantasy, Imaginative Involvement, and the Development of Suggestibility
}

Martin W. Ham

University of Rhode Island

Follow this and additional works at: https://digitalcommons.uri.edu/theses

\section{Recommended Citation}

Ham, Martin W., "Goal-Directed Fantasy, Imaginative Involvement, and the Development of Suggestibility" (1975). Open Access Master's Theses. Paper 1598.

https://digitalcommons.uri.edu/theses/1598

This Thesis is brought to you for free and open access by DigitalCommons@URI. It has been accepted for inclusion in Open Access Master's Theses by an authorized administrator of DigitalCommons@URI. For more information, please contact digitalcommons-group@uri.edu. 
GOAL-DIRECTED FANTASY, IMAGINATIVE INVOLVRMEAT, AND THE DEVHLOPMENT OF SUGGESTIBILITY

BY

MARTIN W. HAM

A THESIS SUBWTTTED IN PARTIAL FULFIILMENT OF THE REQUI RTMENTS FOR THE DEGRE OF

MASTER OF AFTS

IN

PSYCHOLOGY

UNIVERSITY OF RHODE ISLAND

1975 


\section{ABSTRACT}

Studies have repeatediy demonstrated a developmental trond in suggest1b1l1ty -- responsiveness to suggestions trad1t1onally assoclated with the term hypnotism is low for those under a1x years of age, I1ses to a peak near the ages of nine through eleven, and progressively declines thereafter. It has also been consistently shown thet with adult populations, Involvenent in task-relevant inggin1ngs, functions as a cognttive strategy enhancing response to suggest1on. On the basls of evidence such 8 s this, at least one investlgator, J. H1lgand, has suggested that changes in responsiveness wth age are due to varlations in Imaglnative involvenent. Spec1fleally. It hes been proposed that the decline in suggestibility nay be the result of an increased developmental trond torand a rational-logleal mode of thinking, which 1s inconslatent with the involvement in Inaglnative processes so important in responsiveness to suggestion. While the developmental 11terature relating to free fantasylike activity lenis some support to this notion, no previous study has atteapted to deternine eithor a) the relationship botween the passing or faling of suggestions and 1nvolvement in taskrelevant Imaginings in subjects from the lover age levels, or b) changes occurling in these Imaginative involveaents with age.

In the present investigation, one hundred subjects between the eges of eight and seventeen were individually tested in a single 
session. Fach subject was administered standardiged task-motivational instructions followed by an aria-levitation suggestion, an am-catalepsy suggestion, and an annesia suggestion for the number foux. Bech subject was intervlewed innediately after his response to eech suggestion to deterinine whether or not he engaged in suggestion-related 1naginings and, if so, the elaborateness and duration of these inginings.

It was found that, regardless of age, subjects who passed the suggestions a) tended to report engaging in suggestion-related 1maglnings, whereas those who did not respond wero less $11 \mathrm{kaly}$ to engage in this pettern of Inaginative responding, and b) roported engaging in Inaginings that were more elaborate and of longer duration than those who failed the suggestions. In addition, partial support was obtained regarding the not1on of age trends in inaginat1ve 1nvolvenent. Glaborateness and duration of imaginings were characterist1cally low for the youngest ubjects, rose to a peak around the ages of ten to twelve, and declined thereafter. However, andyoes Indicated that only for elaborateness of imaginings In response to the annesia suggestion was there a signiflcant curvilinear relation w1th age, the remaining relationships, while in the same direction, did not achleve oonventional levels of signiflcanco. It is suggested that future research considering developmental tronds in Imaglnative involvenent aay prove to be nore product1ve if varlations are exanined across one-year age groups, and a larger battery of test suggestions is enployed. 


\section{ACKONOHLEDE EYENS}

I would like to acknowledge the help of the many people who aade this thesis project posalble. Flrst, although they wish to ramain anonyous, I want to thank the admintstrators, teachers, parents, and etudents of the school aystem in which this research wes carrled out for thelr cooperation and patience. I also thank Dr. Albert Lott and the other menbers of my confenttee for their active interest and for patiently reading and laproving upon this manuscript. For stimulating and crtical discussion of many aspects of this projeot, I would $11 k$ e to thank my frlend and colleague, Dr. John Chaves. A special debt of grat1tude goes to Drs. Theodore $\mathrm{X}$. Barber and M1cholas Spanos. It was Dr. Barber who flrst introduced me to hypnosis as a researoh area and provided we with the opportunity to develop my skills. Both he and Dr. Spanos have unselfishly fiven innuarable hours in discuseling and encouraging my research interests, and have served as constant sources of 1nspiration for nev 1deas. Last, but certainly not least, I would 11 ke to express my most sincere appreciation to my utfe, Marle, for her persistent encouregenent, moral support. and understanding. 
TAEL OF CONTENS

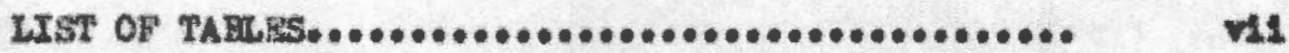

LIST OF FIGURE.

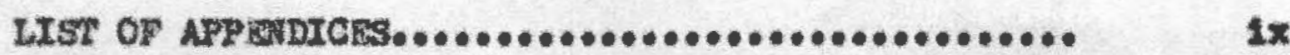

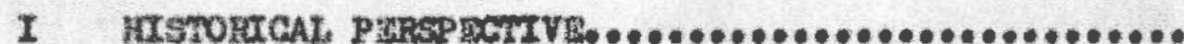

II IMAGINATIVE PROCISSBS AKD

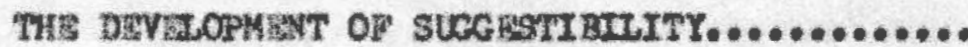

III METHODOLOCY,

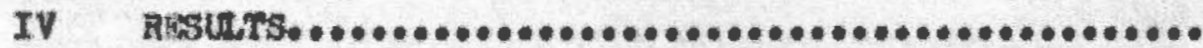

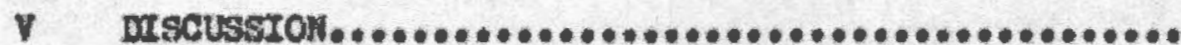

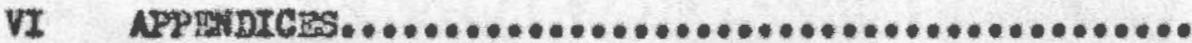

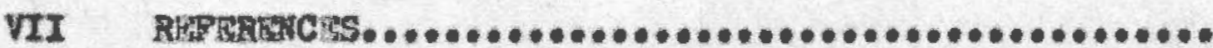


LIST OF TABLES

Table

1 Relationshlp Betreen Performance on the ArmLeritation Suggestion and Bngagement in GoalDlrected Fentagy for Enoh Age Group.....................

2 Relationchip Betwoen Performanoe on the Selective Annesia Suggestion and Ingagenent in Goal-Directed Fantasy for Each Age Group.........................

3 Sumary of Mann-Inttney U Tests Comparing the Haboreteness of Fantasy Roports Provided by Subjects Who Passed the Ar-Leritation and Selective Annesia Suggestlons With that of Subjects who Falled..........

4 Sumary of Hann-Whitney U Tosts Couparing the Duration of Fantasy Reports Provided by Subjects who Passed the Axm-Leritation and Selective Amnesia Suggestions

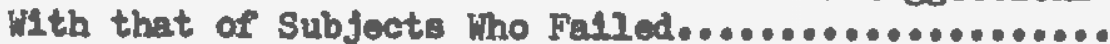

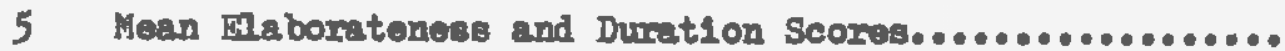




\section{LIST OF FIGURRS}

Figure

1 Mean Haborateness and Durstion Scores Across

Pege

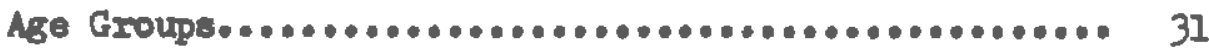




\section{IIST OF APPENDICES}

Appendix

Page

A Fom Letter Requesting Participation............... 41

B Manual for Scorlag Goal Dlrected Fantany............ 42

C Manual for Scorling Haborateness and of Suggestion-Rolated Ineginings................. 52 


\section{HISTORICAL PERSPECTIVE}

Four sets of phenowena have treditionally been subsuned under the rubric of hypnotism. These include: a) heightened responsiveness to suggestions for arm lowerlng, hand anesthesia, visual hal1ucination, selective amnesia, and the like; b) observable changes in posture and movements such as 11mpness-rolaxation, lack of spontanelty, flxed gaze, and peychosotor reterdation, c) reports of unusual alterations in body feelings suoh as ohanges in the size of the body or bods parts and feelings of unrealitys and d) postexperimental reports of havins entered unique state of consclousness.

Historteally, a varlety of theorles have been put forth in an attempt to explain the occurrence of phenomena such as these. Yet, one conceptualization has been dominant for the past 100 years. Basic to this conceptualieation, which has conanly been labelod the trance-state approach, are two assumptions!

1) When a Itualist1o ceremony comionly labeled es hypnotic Induction procedure is sucoeseful, a unique state of consclousness is 1nduced which differs fundanentally from the waking atate. This state has been varlously terned as the hrpnotle state, trance, or hypnosis.

2) The four sots of phenomena traditionally subsued by the term hypnotisin result from the operation of this unique trance state. Moreover, the deeper this state, the more readily these phencinent are manlfested. 
Although the trance-state conceptualization has been dominant during the past century, critics have perlodically asserted that the occurrence of hypnot1c phenomena need not be assumed to result from the operation of an unusual state of consclousness. For instance, as early as 1823, Alexander Bertrand concluded that:
"...The psychological phenomena observed during
the (hypnot1c) state are not exceptional, but are nomal, or at least phenomens which can be observed under varlous conditions. Axtiflcial somnanbulism... servos merely to render consplc- uous and to amplify phenomens dependent upon the working of the general laws of 1magination, expec- tant attention, and desire" (Bertrand, clted in Janet, 1925, vol. I, p. 157).

Nearly a quarter of a century later, James Braid, In his theory of monoldeism, wrote that, "hypnotism occurs only if the subject knows what is expected of $\mathrm{hlin}$ and voluntarily conforms to the demands of the operator (hypnotist) (Bra1d, 1843). More recently, Amold (1946) proposed that subjects respond to suggestions and define their behaviour as involuntary (that is, something which seemed to happen to them and which they did not initiate thenselves) when they Imagine situations which would regularly produce the response. Speciflcally, Amold described this process in the following manner: "...There is one condition which nust be fulfilled If the subject is to obey the hypnotist's suggestion, he must 11terally think as the operator wants him to think. In every instance in which 
the subject cannot bo hypnoticed, he roports afterwards elther that he could not forget the absurdity of the situation, porhaps because he kept thinking of something elsej or he admits that he deliberately resisted elther by criticizing the experimenter's procedure to hinself, or by starting to think of somothlng else.... (When given a suggestion) we risualize ournelves in the sitiation whenever it is descrtbed verbeily... we refocus on 1t (the sugesested situation) and thus relive 1t. When the experimenter 1nststs 'your eyellds are Betting heavy' or 'you are falling forward", he 1nvites the subject to imagine hinself in that particular siturtion" (Axnold, 1946, pp. 8-9).

Desplte 1ts histortcal expression, skept101 sm such as this rogarding trance-state assumptions has largely been ignored. Only withln the past two decedes have approeches which do not draw a distinction between hypnotic and other behaviors attained maturity. To a large extent, thls shlft has been due to efforts directed toward pointing out serlous shortcomings in the traditional approach. Speolflcally, three major objectlons have been ralsed. Flrst, there are no valld criterla for the prosumed trance-state. For nearly a contury, investigators have been searching unsuccessfully for a physlological 1ndex which differentiates individuals judged to be hypnot1zed from those judged to be avake. Not only are thexe no undque physlologieal changes associated with this presumed 
spectel state, but physiological functiontas continuously varies in response to the suggestions which the hypnotic subject is given and with the activites he 18 asked to carry out (Barber, 1961) Chortok \& Kramarz, 1959).

Inasmuch as physlological indices are unavallable, adherents of the trance-state formulation have frequently sugeested that the trance-state can be inferred from trance-l1ke appearance, changes In body feelings, and reports of having been hupnot1eed. However, criteria such as these are invelld because they are deeply embedded In clrcularity that 1s, the presence of a trance-state is Inferred from subjects ${ }^{\prime}$ trance-11ke appearance, changes in body feelings, and reports of having been hypnotized, and, turning around full-clrcie, these phenomena are then explained by stating that the subjects aro in a trance-state (Barber, 1969).

As noted previously. the trance-state formulation assumes that helghtened responsiveness to suggestion is the result of the operation of a unique state of consolousness. It follows from this that non-hypnotio subjects should exhiblt little, if any. response to suggestlons for ars lowering and levitation, hand anesthesla, visual halluclnation, selective anesie, and the 11ke. Experinental evidence, however, has falled to support this notion. Rather, It has been consistently demonstrated that a surplisingly high proportion of subjects, who have not been exposed to an hypnotic Induotion procedure, respond to test-suggestions. For example. Barber and Calverley (1964) found that in a group of control subjects. simply told to "Imaglne" the suggestions they were given, between one-th1rd and one-half reported the occurrence of vivid autitory and visual hallucinations. Sivilarly, a number of other 
1nvest1gators (Anderson \& Sarbin, 1964, Hilgand \& Tart, 1966, Sarbin \& Anderson, 1963, Sarbin \& Juhasz, 1967) have shown that subjects, who have recelved no spocial prollminary instructions, are only slightly loss responsive to motoric and perceptual suggestions than are subjects who have recelved an bypnot1c 1nduction. Bven more problenatic for the traditional perspective is another set of recent flndings brief 1nstructions, which encourage subjects to try to the best of their abllities and inform then that the tasks to be performed are easy, enhance subjects' responsiveness to suggestion to the same extent as do traditional hypnotic Induction procedures (Barber, 1965a). Several trancestate theorists (Evans, 1968, H1Igard, 1969, H1Igard \& Tart, 1966, Schneck, 1969, Wachtel, 1969) have argued that these flndings way be the result of susceptible subjects "slipplng epontaneously into e trance-state." However, in Iight of the fact that the trance state cannot be inferred wthout clrcularity, this anguent would seer unjust1flable.

In add1tion to demonstrating varlous inadequacles inherent in the traditional conceptualization of hypnot1sm, research efforts during the past tro decades have also ied to the development of a number of nonstate formulations. In general, the nonstate viowpolnt stresses the sinilarty between hypnotic behavlors and other psychological phenomena and argues that hypnotic behavior can be explained in terns of social paychological constructs. More specifically, one way of conceptuallzing the hypnotic situation, which has gained much recogrition in the past fer years, is the cognitive-behavioral approach (Barber, 1969, Barber \& Ham 1974 , 
Barber, Spanos, \& Chaves, 1974, Spanos \& Barber, 1974). Th1s approech assumes that two interrelated factors underlie the four sets of phenomena traditionally assoclated with the term hypnotisn, These are,

1) The wllingness of the subject to cooperate with the experimenter that 18, the good hypnotic subject 18 an individual who views hypnosis as interesting and worthwhlle and who desires and expects to experience those thinge that are susgested.

2) A shift from the pragratic, reality-testing orientation of everyday $11 f e$ to one of involvement in imaginings related to suggestions presented by the experidenter. This involves both carrylng out and developing patterns of imeginings consistent with the sugsestions and setting aside information about the real world inconsistent with the suggeations.

Thus, this approach likens the responsive hypnotic subject to an Individual in a novie or theater audience who expertences the thoughts and enotions the actors are attempting to arouse (Barber, 1972). In both 1nstances, the 1ndividual is seen as one who has positive attitudes, mot1vations, and expectancles toward the communications he is recelving. Given this positive set. both are wlling to suspend a crltcel, reality-testing perspective and become imaginatively involved in the communcations. In this thesis, a number of Implications of this nonstate approach torard hypnotisn will bo considered with respect to the developmental trends in suggestibilty. 


\section{II}

IF:AGINATIVE PROCSSSES AND

THE DEVELOPMENT OF SUCGESTIBILITY

Botween the Jenr 1894 and 1940 , a nuber of studles were oonducted

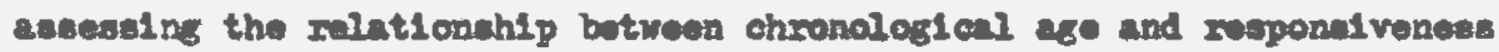
to the type of augeatione tinditionally eseodated wth tho word hyp-

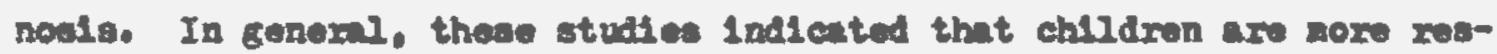
ponelve to euggeotion than are adulte. For aruple, Feasorahdat (2933).

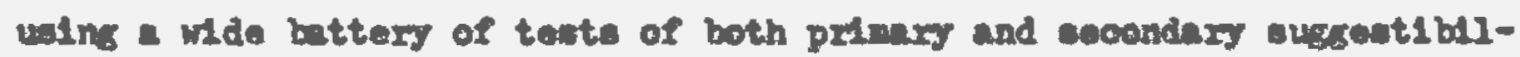

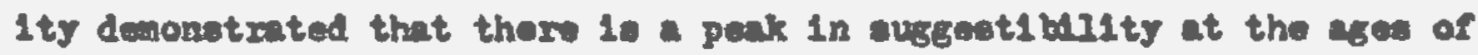
sevon to aght and that after the age of twonty ouggetibilty appenz to lovel off. Feyent and Kohn (1940) conflraed this trond on the base of

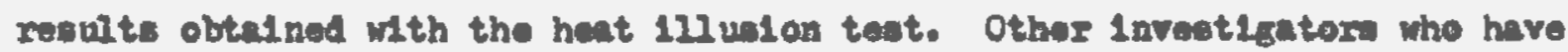
reported elaller Irdinge Include Blnot (1900). Bxanull (1930), G11burt (1894). G1roud (1911), Guld (1908), Pepor (1926), Rose (1908), Shernan (1925) and $\sin 11(1896)$.

One dffleulty ith most of those enciler otudied is that thay employ

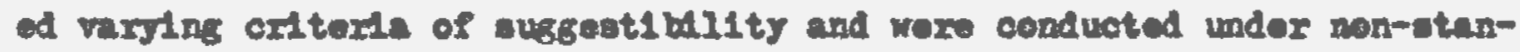

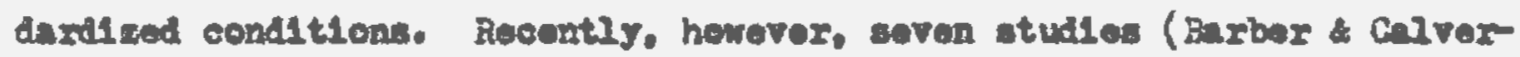
1es. 19631 cooper tondon, 1966, 1971, Lendon, 1965, Iondon cooper.

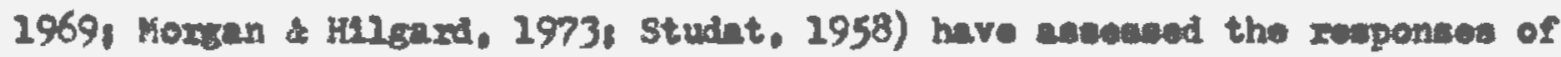

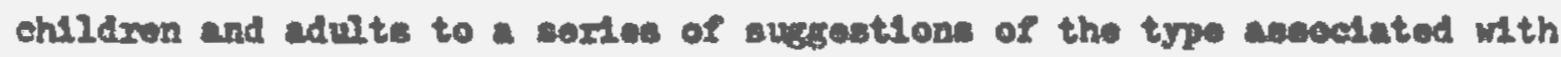

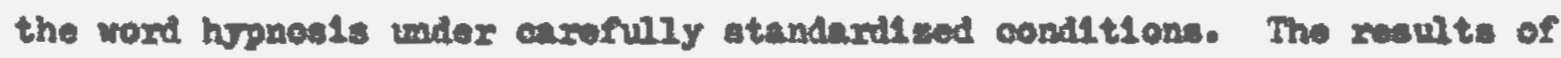

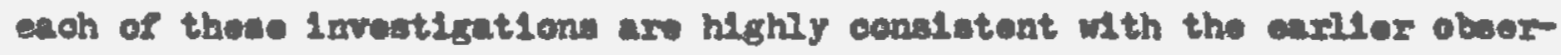
vetion in that they denonotrate a alen dovelopaental trond in oussontibl-

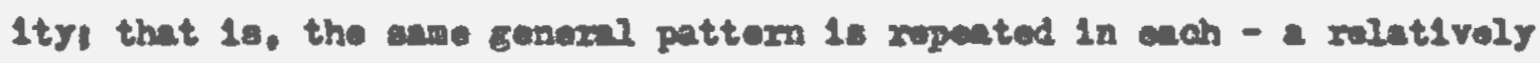

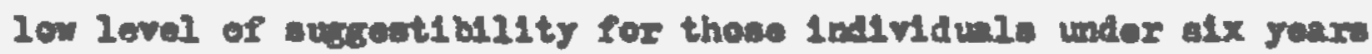


of age, a rise to a peak neax the ages of nine through eleven, and a progressive decline thereefter. Thus, the effects of age on suggestibllity appear to be falrly well established. However, the factors contilbutins to this rise and fall in suggestibility have not received systematic consideration.

As noted in the preceeding section, one way of conceptualizing the hypnotic or suggestion situation is that the subject shlfts from the pregnatic, reality-testing oxlentation of everyday ilfe to an oxientation of make-belleve. Thus, in this type of setting a premi un is placed upon fantasy and Imagination (Shor, 1959; Spanos, 1973; Sutcllffe, Parxy \& Sheehan, 1970). Accordingly, a number of . stuales (Anderson, 1963; As, 1962; As, O'Hara, \& Mungar, 1962; Atkinson, 197; Barber \& Calveriey, 1964b; Barber \& Glass, 1962, Coe, 1964; Goe \& Sarbin, 1966, J. Hilgard, 1970; 1974, Lee Teng, 1965; Sarbin \& L1m, 1963; Shor, Orne, \& O'Connell, 1962; Spanos \& MoPeake, in press; Spanos, Valois, Ham \& Han, 1973; Sutcllffe, Perry \& Sheehan, 1970, Tellegan \& Atkinson, 1974 have consldered the relationship between general capacity for imagery or fantasy and suggestibility in adult populations. With a single exception (Barber \& Calvexley, 1964b) a signiflcant positive relation has been Indieated. For Instance, Barber and Glass (1962), J. Hilgard (1970), J. Hilgard (1974), Spanos and Mopeake (In press), and Tellegan and AtkInson (In press) found that subjects who tended to become imaginatively involved or absorbed in such everyday activities as daydreaming, reading a novel or pootry, watching or acting In dramatic productions, 11stening to music and the $11 \mathrm{ke}$, tended to be responsive to hypnotle suggestlons. Along slightly 
different 1ires, other Investigators (Shor, Orne, \& $0^{\circ}$ Connell, 1962; Spanos, Valo1s, Ham, \& Ham, 1973, Sutcllffe, Perry, \& Sheehan, 1970) have obtained results indicating that, for certain populations, vividness of Imagezy is positively corzelated whth suggestibility.

While a number of studies have attempted to assess the relation of general expacity for 1magery and fantasy inth suggest1 bllity, onIy recently has the direct effeet of imaginative involvenent on responsiveness to suggestion been Investigated. Speciflcally, a sexies of studies (Spanos, 1971, Spanos \& Barber, 1972, Spanos \& Hem, 1973) Indicated that subjects who experlence their responses to suggesticns as Involuntary occurences typlcally engage in a pattern of Imagining which has been labeled goal-directed fantasy. When responding to suggestions, these subjects often imagine situations, whlch if they were actwally to oceur, would bring about the suggested effect. Thus, subjects who passed the suggestion for am-heaviness typleally reported fantasles such as the following:

I Imagined that there were all kinds of rocks tied to my am. It felt heavy and I could feel $1 t$ golng down. I couldn't stop 1t. (Spanos, 1971). Stmilarly, subjects who passed the am-levitation suggestion conmonly gave testimeny such as the following:

I imagined that my am was hollow and semebody was putting air into 1t, that ny am was hollow, there was nothing in 1t, and somebody was putting alr Into it (Spanos, 197). In contrast to this, subjects who did not respond to suggestions usually falled to engage in this pattern of imaglnative responding. 
Instead, these subjects were elther unwilling to sooperate or unable to adopt the attitude of inagining Implied by the suggestions. Additional evidence relating to the importance of Imaginative processes cames from studfes Indleating that; (1) suggestions aro more likely to be experlenced when they direct the subject to engage in imaginings that aro consistent with the alms of the suggestion (Barber \& Calverley, 1969, Barber \& Hahn, 1962; Chaves \& Barbor, 1974; Cos, Allan, Krug \& Wurzmann, 1974; Evans \& Paul, 1970; Johnson, 1973; Spanos \& Barber, 1972; Spanos, Barber, \& Lang, in press, Spanos \& MoPeake, 1974), (2) highly suggestible subjects tend to report Imaginings that are nore elaborate and of longer duration than are those of subjecte rated medium or low in suggestibility (5panos, 1973), and (3), the procedures most effective in increasing the suggestibility of unresponsive subjects consist of training subjects to become involved in specific suggesticn-related imaginfings and to become involved in specific suggestion-related Imaginings and to disattend to corpeting thoughts and sensory input (Commins, Furlam, \& Barber, 1973; Dlamond, 1972, Sachs, 1969, 1971; Sachs \& Anderson, 1967).

From the abuve discussion, it is apparent that a major factor deternining level of suggestibility is the subject's willingness and ebility to engage in circumscribed pattezns of 1magining. It follows from this that the xise and fall in suggestibility with age may, at least in part, be due to developmental trends in capabilities for imagery and fantasy. More spocifically, the progressive decline in suggestiblilty after ages nine to eleven may be a result of an increased developmental trend toward a rational-logical mode of thinikIng which is inconsistent with the involvement in imaginative pro- 
cesses so important in responsiveness to suggestion.

The avallable data regarilng imaginative behavior exhibited durIng play and daydreaming appear to be consistont with this hypothesis! that is, they Indicate specifle developaental trencis in the structure and content of Imaginative behavior. For example, Plaget's (1962) systenatic observetions of overt play fron bith to puberty led him to conclude that symbollc play (which involved make-believe representation of absent cbjects) commences at about the end of the first yeari that the symbolism in play adheres ever nore closely to reality after about the fourth rears and that play eventually becomes less "Imaginative," with symbolic constructions less distorting and more nearly related to adopted work. S1milarly. Markey (1935), Pitoher and Prelinger (1963). Ames (1966), and Hurlock (1964) found that self-Initiated fantasylike play, daydreaming and the capacity for Imaginative storyteiling begins eaxly in childhood around the socond or thind year. Aiso consistent with Plaget's finding are those of other Investlgators (Liohman \& Witty, 1927, Jors1Id, ilaxikey. \& Jers11d, 1933; Snith, 1904) indicating a trend toward increasing realism in daydreams and play between the ages of flve to twelve.

In addition to observatlons regarding developmental changes In the stmucture and content of fmaginative behaviors, investigators have also reported belief in the reality of fantasylike activities may also undergo changes with age. Thus, Plaget (1962) commented that:

The two to four-year-ald child does not consider whether 
his Iudie aymbele are reel or not. He is amere in a sense that they are not we for others, and makes no sexious affort to porsunde the adult that thay are. But for him, it 15 quetion whioh does not axtse, bersuse aymbolle play Is direot sattsfaction... and has its own ledind of bolief, whioh 19 a cubjective reality. In the case of older ch1ldron. In whose play the symbols are replaced by rules, It 1 obvous that the effect of soeled 11 fe 18 to weaken lut1o bal1ef (p. 168).

Jerst1d (1957) and Yarrow (1960) are goneraliy in agreement with Plaget in polnting out that as the chlid moves towerd adalascanoe, his gormIng avareness of reality intrudes upon his inagindings and, ag a roault, he tends to lose the abluty to bocone involved in mako-balleve so vivid that it soans almost real.

To sumarize, suggestiblity is low for those under the age of 6L. Hses to a high polnt near the ages of alne to eleven, and progrosively declines thereafter. Responsiveness to susgestion appests to Involve the capectity to dirot one's Imaginings along ouggested 11 nes and to temporarily treat these lmaginings as real oceurrances. Rosearch in freo fantasyluke acltvity has indioated that the indivdunl's ablity to engege in structured reolity-orlented Imagininge compianos at about the age of three years and inurvases thereafter. On the other hand, it has also beon ahom that bellef in the reallty of these inaglnings begins to deollne as the chlld appronches adoleacence. The Interplay of these two capacities may, in part, acoount for the devalopmentel tronis in ougestiblity.

The purpese of the present study 18 to:

(1) Doteratne the relationahlp betweon the passing or falling of an 1deonoter (arm-levitation), a challenge (arm-catalepsy), and an 
amesia suggestion and the presence or absence of goal-directed fantagy in subjects between the ages of elght to seventeen.

(2) Determine changes ocourlng in the elabomteness and duration of goel-directed fantasy with age and how these changes relate to suggest1b111ty.

It is hypothesized that,

(1) W1thin each age group. subjacts who pass suegestions for am Iovitation, arm catalepsy, and selectlve amnesla will tend to report ongagine in gcel-directod fantasy, whereas those who do not respond to these suggestions 111 be loss 11kely to engage in this pattem of inaglnative reaponding.

(2) within each age group, subjects who pess each of these suggest1ons w1I roport ongaglne in goal-directed fantasises that are more elaborate and of Ionger duration then those of subjects who fas. these suggestions.

(3) There 111 be a curvilinear relationship between the elaborateness and duration of goal-directed fantasy and age. 
METHODOLOGY

\section{Overall Design}

One hundred subjeots, (44 males and 56 fenales), botween the ages of 8 and 17 were Individunlly tested in a single session by one experfinenter (the author). Each subject was administered standardiged task-motivational instructions followed by an arm-levitation sugsestion, an arm-catalopay suggestion, and an anneala suggestion for the numbr four. Wach subject was intervlewed innediately after his ro sponse to each suggestion.

\section{Selection of Subjects}

After arrangenents have been made with school offlolals and at least one month prior to conducting the experiment, parents of childron from participating schools wero sent a lotter requestiag permission for their child to participate in a study investigating the development of Imaginative behavior (see Appendix A). From the total number receiving permission to participate, 20 subjects were rendomly selected from the followling age groups, 8-9. (Groupl), 10-11, (Group 2), 12-13, (Group 3), 14-15. (Group 4), 16-17, (Group 5). None of the subjects were pald for their particlpation.

\section{Procedure}

Prelininery instructions. Iminediately upon enterlng the experimental room, each subject wo seated and adeinistered the follow 1ng instruotions orelly:

I an Interested in what $1 \mathrm{~s}$ going on in peoples" minds when they carry out suggestions. I'm Interested in what they are 
thinking, ineglaing, ploturing, feeling, and saylng to thencelves while carryling out suggestions. In thls experiment, I an going to esk you to carry out some suggestions. After each suggestion, I'Il ask you to tell we what was paseing through your mind whlle you vere carrying out the auggest1on. In giving we your answer, 1t's very limportant that you be honest and tell me everything that you were think1ng, Imaglining, plcturing, feeling, and sayling to yourself - even if you thlnk it s111y or unimportent.

following this, each subject was asked to deserl be in his orm words the purpose of the experiment. The instruotions rere repeated and clarffled for those who fail to indleate a balc understanding.

Tack-motivational instructions. Next the experlnenter adrinistered task-motivating instructions. These instructions took approx1mately 30 seconds to adminlster and nere yorded in the following manner:

I an now going to test your ability to lmagine and to visug1ze. It is really quite easy and you will probabiy find it very interosting. All that is involved in responding to these suggestlons is that you relax and let yourself inagine and picture the things I w11l ask you to 1magine. Most people are able to do this very well without any diffleulty. When they try to the beet of their ability, they are able to Imagine very vividy the things deseribed to thein. If you try to imagine to the best of your ability you too can easily inagine and do the interesting things I tell you. All I an aaking 
for 18 your cooperation in helpling this experiment by trying your best to 1 maglne what I describe to you. Now close your eyes, lat your whale body relax and make yourself ready to recelve the flrot suggestion.

Inediately following completion of these instructions, the aubject wes adulnistered the flxst of three suggestions.

Adninistzation of suggestions. The first suggestion administered wes for arm-levitation. This suggestion, which 18 sinilar to that employed by Barbor (1969), took approxinately 30 seconds to adninister and was worded in the following annert

Hold your right arm stralght out in front of you. Ingine that the arm $1 \mathrm{~s}$ beconing 11ghter and 11ghter, that 1t's moving up and up. It's velghtless and rleing in the air. It's lighter and lighter, rising and lifting more and more. It's lighter and lighter and moving up and up. It's moving up and up, more and more. It's lighter and 11ghter, noving up and up, more and nore, higher and higher.

At the end of the 30 -second suggestion perlod the subject was told "Iou can relax your am now." Bech subject was then questioned concerning his experlences during the sugge日tion interval. Following this procedure, the subject we admintstered the following arm-catalepsy euggestion!

Hold your left am straight out in front of you. Imagine that your an is in a cast so that the elbow cannot bend. Imagine that the cast ilakes the ard stiff, Igld, and Im- 
movable, it keeps the elbor from bonding. Your arm cannot bond, 1t's held t1ghtly by the cast, st1ff and Flid, so ot1ff and Mfld that $1 t$ won't bond no matter how hard you try. It's otiff and Ifld, otiff and rgid, hold tightly by the cast. The nore you try to bond 1t, the st1ffer it w111 becoase. You won't be able to bend It until you hear ay fingere snap.

The experfinenter then walted five seconde and sald "Try to bend your arm, you can't." After wating flve more seconds, he snepped his fingers and instructed the subject that he was now able to bend his arm. The subject was then interviewed conoerning his experiences. Upon conpletion of this questioning, a sective anneala suggestion was administered. Thls suggestion wa taken verbatin from Spenos (1971) and was worded as follows:

I want you to forget the number four. I want you to wipe the number completely from your alnd so that you are unable to think of, recall, or reanber the nubor four in any way. The nuber four w111 bo gone completely from your aind. You'1l bo unable to think of. recall, or remeaber this number in any way unt1l I instruct you to reneaber $1 t$. After wafting 30 eeconds, the subject was instructed to count out loud from one to flve. After responding to the sugsestion, he was agsin asked a serfes of questlons reganding his expertences.

Sem1-structured intervlers. Each subject was interviened on throe epparate cocasions during the course of the experlmental session, once after each sugsestions, The first four requests for testimony follow- 
ing each susgestion wero rorded in the following manner.

(1) Please tell we honestly what wes pessing through your Ind-whet you wero thinking about and saying to yourself. 1nagining and pleturing in your head from the time I asked you to (Imagine that your arm wes Fing) unt1l the time I asked you to stop responding to this suggestion. (The phrase in brackets w1l be replaced with the phrases, Imagine cast on your aIn, fonget the number four. following the am-catalepsy and amnesla suggestions, rospectively.)

(2) Please tell we more about what you were expexiencIng during this tine. Don't leave anything out. Tell me overything that you can remember.

(3) What were you laggining at this time? What plctures wert in your mind?

(4) that were you thiniding about and saylng to yourself at the tine?

Subjecta, whose testimony indicated that they engeged in gouldirocted fantesy, were also asked,

How long did the targe last? During the time that you wero responding to this euggestion, did you lnegine (brlef desoription of reported imagining) for the ent1re time, most of the time, half of the tine, ox only a short part of the time?

The questioning was terminated at this point for those subjecte who elther olearly did or did not report goal-dilrected fantasy. 
Subjects who did not oupply detalled enough 1nforeation for the experimenter to unambiguously make this judgement were asked questions almed at clarifying theis reports. Mese questions took the form of asking the subject to describ nore fully certain aspects of his expertence.

\section{Dependent Variables}

The major dependent variables essessed in this study included: (a) subjects" overt response to the arm-levitetion, arm-catalepey. and anosia suggestions; (b) subjects' testimony for goal-directed fantasy in response to these suggestions; (c) elaborateness of ported goal-directed fantesies, and (d) duration of reported goaldireoted fantasles.

Overt response to szm-ovitation, axm-catalepsy, and amessia suggestions:

Subjects were scored as passing the arm-levitation suggestion if they raised thelr arm four inches or more durling the 30-second suggest1on pertod. Subjects were scored as passing the arm-catalepsy suggestion if they falled to noticeably bend thelr and at the elbow before the experimenter snapped his flngers. Subjects were scored as passing the eranesla suggestion if they falled to say the number four while counting out loud from one to flive.

Assessment of goal-directed fantasy. A scorlng manual describins the characteristics of goll-directed fantesy has been developed by Spanos (1971) (see Appendix B). The experlmenter used th1s manul in judglng subjects" testimony following each suggestion for the presence or absence of goal-directed fantasy. In order to establish the intermer rellability of the experimenter's judgments, a socond Independent rater post-experimentelly juiged the tape-recorded 
verbal interchanges obtained after the admlnistration of esch suggest10n. Discorient judements were resolved by aseigning the subject the average of the two ratings.

Assessment of duration. Subjects who 1adicated that they engaged in goal-directed fantasy were asked to approximate the duration of this experfence that 1s, they were asked to judge whether the fontasy lasted for the ent1re tine they were responding to the suggestion, for wost of the time, for half of the t1me, or for only a short part of the time. These alternatives were scored $4,3,2$, and 1 , respectively.

Reliability of Goal-Directed Fantasy Ratings and Flaboratenoss of Sugzestion-fielated Ineginings Batings. The two Judges rated a total of 300 verbal 1aterchanges for the presence or abence of goal-dirscted fantasy, and the elaboriteness of suggestionrelated lmaginlngs. A high level of inter-rater efreenent was shom for both. The judges agreed on 292 of their 300 rating cholces (97\% of the time) that goal-directed fantasy was or was not displayed in subject's testimony $\left(x_{p}=0.94\right)$. Similarly, with respect to ratings of level of elaborateness of suggestion-rolated Imaginings displayed in subject's testinony, the judges agroed on 270 of their 300 rating cholces ( $90 \%$ of the time) ( $m 0.93$ ). 


\section{IV}

\section{RESULTS}

As noted in the preceeding section, three sugsestions were adninistered to all eubjocts durlis the experimentel session - an arm-levitation suggestion, and arm-catalepsy suggestion, and a seleotive amnesia 34sgertion. Initial inspection of the data from the amcatalepsy suggestion indicated that it was passed by almost all of the subjects; that 1s, In rone of the five groups did nore than three subjects fall to meet the ciltexia for passing this suggestion. Specifically" the number of subjects falling this suggestion in Groups 1 through 5 was 1, 2, 0,3, and 3, respectively. This may have been due to the fact that this suggestion, unlike the other two, included an explic1t goel-directed fantasy. However, whatever the reason, because of the extremely low rate of fallure on this eusgestion, analyses conaldering the reletionships of gosl-directed fantasy, elaborateness, and duretion rith responsiveness could not be performed. Therefore, the arti-catalepey deta were not analyzed or included in this report. Goel-D1 rected Fantasy and Responsiveness to Suggest1on

Table I shows the ralationship between goal-directed fantasy and subjects" tendencles to pass or fall the arm-levitation suggestion for each age group. Flsher exret probability tests periolmed on these data clearly indicate that, in ecch age group, subjects who pess this suggestion tend to report goal-directed fantasy while those who do not pass usually fall to report such fantasy ( $p<.005$ for each age group). 


\section{TABLE 1}

Relationship Between Performance on the ArmLevitation Suggestion and ingagement in GoalDirected Fantasy for tach Age Croup

\begin{tabular}{|c|c|c|c|}
\hline & Group $1(8-9)$ & $\begin{array}{l}\text { Goal- } \\
\text { Directed } \\
\text { Fantasy } \\
\text { Present } \\
6\end{array}$ & $\begin{array}{l}\text { Goal- } \\
\text { Directed } \\
\text { Fantasy } \\
\text { Absent } \\
\quad 2\end{array}$ \\
\hline \multirow[t]{2}{*}{ Passed } & Group $2(10-11)$ & 8 & 3 \\
\hline & Group $3(12-13)$ & 11 & 0 \\
\hline \multirow[t]{3}{*}{ Suggestion } & Group $4(14-15)$ & 7 & 0 \\
\hline & Group $5(16-17)$ & 8 & 0 \\
\hline & Group 1 (8-9) & 0 & 12 \\
\hline \multirow[t]{2}{*}{ Felled } & Group $2(10-11)$ & 1 & 8 \\
\hline & Group $3(12-13)$ & 2 & 7 \\
\hline \multirow[t]{2}{*}{ Suggertion } & Group $4(14-15)$ & 1 & 12 \\
\hline & Group $5(16-17)$ & 4 & 8 \\
\hline
\end{tabular}


The relationship between the presence or absence of goaldirected fantasy in subjects ${ }^{\circ}$ tectinony and passing or failing the selective amnesia suggestion is displayed in Takle 2. Again, Fisher tests indicate that subjects who pass or fall this suggestion differ In this respect $(p<.05, p<.001, p<.025, p<.05$, and $p<.025$ for Gxoups 1 through 5, respectively).

\section{TABLE ?}

Relationship Between Perfornance on the Selective Amnesia Suggestion and Angagement in Goal-Directed Fantasy for ach Age Group

\begin{tabular}{|c|c|c|c|}
\hline & & $\begin{array}{l}\text { Goal- } \\
\text { DIrected } \\
\text { Fantasy } \\
\text { Present }\end{array}$ & $\begin{array}{l}\text { Goal- } \\
\text { Directed } \\
\text { Fantasy } \\
\text { Absent }\end{array}$ \\
\hline & Group I (8-9) & 7 & 3 \\
\hline \multirow[t]{2}{*}{ Passed } & Group $2(10-11)$ & 12 & 0 \\
\hline & Group $3(12-13)$ & 10 & 0 \\
\hline \multirow[t]{3}{*}{ Suggestion } & Group $4(14-15)$ & 9 & 0 \\
\hline & Group $5(16-17)$ & 6 & 0 \\
\hline & Group I (8-9) & 2 & 8 \\
\hline \multirow[t]{2}{*}{ Falled } & Group $2(10-11)$ & 1 & 7 \\
\hline & Group $3(12-13)$ & 5 & 5 \\
\hline \multirow[t]{2}{*}{ Suggestion } & Group $4(14-15)$ & 6 & 5 \\
\hline & Group $5(16-17)$ & 5 & 9 \\
\hline
\end{tabular}


The testimony of subjects who passed these two suggestions was renarkably uniform. Wth the exception of 5 subjects on the armlevitation suggestion and 3 on the selective amnesia suggestion, these subject.s reported visually Imagining situations which, if they were actually to occur, would lead them to experlence the sugerested effects. For example, one subject who passod the arm-levitation suggestion provided the following fantasy report:

I felt l1ke I was some kind of leaf and the tree just threw me off. At flrat I felt really heavy. Then all of a sudden a big gust of wind just throw me up off the ground and I just started spinnins and spinning and I couldn't stop golng up. ... I could see trees, blg. big. blg trees and all the other leaves were watching ne. L1ke I was the only one and I kept going up and up. Then when you sald to let 1 ( $\mathrm{my} \mathrm{sm}$ ) drop, the wind died and I fell. It was like it was as high as I could go and that was all. I Just crushed and fell to the ground.

The testimony of other subjects who passed this musgestion included references to their arms belng hollow, changing into wings, or belng attached to kites and balloons. Along similar lines, the most frequent report of subjects who passed the selective anresia sufsestion was that they imagined a number 11 ne with elther the 4 initially missing or disappearing by various means (e.g." fading out, erased, crossed out, walk1ng away). 
In centrast to the reports of subjects who passed these suggest1ons, the testimony of those who falled was rether varled. In a fer Inetances, subjects Indleated that they were not motivated to cooperate. For the ost part, hovever, their testimony ahowed that they vere well sotivated but unable to dovlse a strategy that would lead them to successfully experlence the suggested effocts. The followIng report is characterlotics

Si I was 11ke saying to myelf "I hope I don't remember the number four unt1l the person (experimenter) 1nstructs we to" and I juat kept asying "I hopo I don't remenber that number." But no mattor how hard I tried I couldn't forgot.

Es How did you go bout trying to forgot?

S1 Just by eaying in wy head $2,2,3,5, \ldots 1,2$, $3.5 . . . "$ over and over agein. If And did this work?

St No, all I could soo was this big number 4 coming at mo. I couldn't knoek out the 4. As shown In Tables 1 and 2, elght subjects ongaged in gowld1rocted fantesy but falled the ans-levitation suggestion and 19 ongaged in such fantasy but failed the selective annosia suggestion. On the whole, the teatimony of these subjecte was like that of those who passed the suggestion with one important exception -most were unable to malntain their fantasy throughout the entiro time in whloh they were responding to the suggestion. The report of the folloring subject who falled the arm-levitation 
guggestion is 11 luatrative:

"I plotured a stage with purple velvet curtains at sohool I used to go to. I could see an audience and a maglelen and ho was levteting my wole body, not just my am. I could see myself sitting on a bench and I was being lifted. I started to nove just a tiny $u t$ and then it (the picture) just stopped. That's whon I notleed that there was no sensation of $\mathrm{ny}$ azm gotting any 11ghter, as a nattor of fact, It was gotting to foel numb and hoavler. Evorything contradicted 1tself."

S1011arly, in all but three inatances, subjects who falled the seleotive annesia susgestion but reported engaging in goal-direoted fantesy indicated that at some point during the suggestion the nuber four resppeared in their fantagy.

As noted oarlier, a enall proportion of subjects pased each of the suggestions whthout ongaging in goal-d1rocted fantasy. Bxamination of this testimony did not indicate that opeciflable altemative strategy had boen employed. Instead, these subjects generally indicated that they had simply overtly complied wthout actually experlenoing the suggested effects.

Mabonteness and Duration of Fantasy and Pesponsivenegs to Surgestion

Subjects testimony following each euggestion was rated for elaborateness of fantasy acconding to the crlterla desortbed in 
Append1x B. Mann-Whitney $U$ tests were performed on these data to deterine whether the fantesy reports of subjects who passed each suggestion differed in this respect from those who falled. Table 3 sumarlzes these analyses for the arn-levitation and selectlve annesia suggestlons by age group. As shown in this table, each of these anelyes proved signifloant, that 18, for all ages, subfects who passed elther the arm-levitation suggest1on or the selectlve amesia suggestion were found to engage in more elaborate fantasy than those who falled to pass these suggestions.

\section{TABLE 3}

Sumary of Mann-Whitney U Tests comparing the Thaboratenese of Fantasy Reports Provided by Subjects tho Passed the Arr-Levitation and Select1ve Annesia Suggestions With that of Subjects tho Falled

\begin{tabular}{|c|c|c|c|c|}
\hline Age Groups & $\begin{array}{l}\text { Su of Ranks } \\
\text { for Subjects } \\
\text { wo Paseed }\end{array}$ & $\begin{array}{l}\text { Sw of Panks } \\
\text { for Subjects } \\
\text { who Falled }\end{array}$ & $\mathrm{U}$ & $\mathbf{p}$ \\
\hline \multicolumn{5}{|c|}{ AFM-LEVITATION SUCGESTION } \\
\hline $1(8-9)$ & 120.0 & 90.0 & 12.0 & .01 \\
\hline $2(10-11)$ & 149.5 & $60 \cdot 5$ & $15 \cdot 5$ & .01 \\
\hline $3(12-13)$ & 146.0 & 64.0 & 19.0 & .025 \\
\hline $4(14-15)$ & 116.5 & 93.5 & 2.5 & .001 \\
\hline $5(16-17)$ & 116.0 & 94.0 & 16.0 & .01 \\
\hline \multicolumn{5}{|c|}{ SELECIIVE AMNESIA SUGGESTION } \\
\hline $1(8-9)$ & 129.0 & 81.0 & 26.0 & .05 \\
\hline $2(10-11)$ & 165.5 & 44.5 & 8.5 & .001 \\
\hline $3(12-13)$ & 137.0 & 73.0 & 18.0 & .01 \\
\hline $4(14-15)$ & 130.0 & 80.0 & 14.0 & .01 \\
\hline $5(16-17)$ & 95.0 & 115.0 & 10.0 & .01 \\
\hline
\end{tabular}


To provide some approciation for the differences which exist in subjects, testimony along this dimension, the following are excerpts from reports gathered after administration of the selective amnesia suggestion. These reports were scored $0,1,2$, and 3 , respectively.

Subject \# I, I tried to forget the number 4. I kept saylng to myself, "Forget the number 4, there's no such thing as number 4, 1t doesn't exist." But all I could think of was $4-4-4 \ldots .$. . I kept soeing this big number 4. That's all I could pleture and I couldn't get rid of 1t.

Subject \# 2, When you flrst sald that there was no 4, I could see a whole mess of sticks. There was one set with one stlok, another set with two stlcks, a sot with three sticks, and a set with flve sticks. I was just ploturing that when you ald to count 1 to 5. Subject \# 31 At flrst I was pleturing everything black except for a number 1 ine that went $1,2,3,4,5$ all the way up to 10 . Then the number 4 went away, It kinda faded out so I couldn't see it anymors and the 3 and the 5 moved together so 1 t would say 1,2,3, 5,6 and so on. Then I was just counting to nyself $7,2,3,5,6 \ldots \ldots$

Subject \# 42 I was inagining a whole group of numbers in this playground with swings and everything. 
The little numbers were chasing one another around and some were sitting around having a clgarette. I saw the 4 walking down this road, just going and golng like noboly wanted 1t. He just kept walking unt1l I couldn't see him anymore. Just the road and the dark banks of sand on the side. I was wondering why they didn't want him. He Just kept walking. Ho had a little knapsack and the corners of $\mathrm{hlm}$ wero hung down like he was really sad. He just kept walkIng and walking and getting swaller and swaller unt1l he was gone.

Additional examples of testimony assoclated with each elaborateness rating for this and the arm-levitation suggestion way be found in Appendix C.

After rosponding to questions reganding the content of their fantasy experience, subjects were asked. to judge the duration of this response. These data were also analyeed by Mazn-Whitnoy $\mathrm{J}$ tests. A sumary of this analysis may be found in Table 4. As Indicated in this table, for all ages, subjects who passed the armlevitation and/or the selective annosia suggeation roported fantasies of longer duretion than those who falled. 
TADLE 4

Sumary of fian-whitney U Tests Lomparing the Duration of Fantasy Reports Provided by Subjects who Passed the Arr-Levitation and Selective Annesia Suggestions With

That of subject: tho Falled

\begin{tabular}{|c|c|c|c|c|}
\hline Age Groups & $\begin{array}{l}\text { Sun of Ranks } \\
\text { for subjecte } \\
\text { who Passed }\end{array}$ & $\begin{array}{l}\text { Sur of Ranks } \\
\text { for Subjects } \\
\text { who Failed }\end{array}$ & U & p \\
\hline \multicolumn{5}{|c|}{ AFA-LEVITATION SUGG SSTION } \\
\hline $1(8-9)$ & 120.0 & 90.0 & 12.0 & .01 \\
\hline $2(10-11)$ & 150.0 & 60.0 & 15.0 & .01 \\
\hline $3(12-13)$ & 152.0 & 58.0 & 13.0 & .01 \\
\hline $4(14-15)$ & 118.0 & 92.0 & 1.0 & .001 \\
\hline $5(16-17)$ & $222 \cdot 5$ & $87 \cdot 5$ & $9 \cdot 5$ & .01 \\
\hline \multicolumn{5}{|c|}{ SULECIVIS AMNESIA SUGGESTION } \\
\hline $1(8-9)$ & 132.0 & 78.0 & 23.0 & .025 \\
\hline $2(10-11)$ & 169.0 & 41.0 & 5.0 & .001 \\
\hline $3(12-13)$ & 134.0 & 76.0 & 21.0 & .025 \\
\hline $4(14-15)$ & 123.0 & 87.0 & 22.0 & .025 \\
\hline $5(16-17)$ & 103.5 & 106.5 & 1.5 & .001 \\
\hline
\end{tabular}


Maborateness and Duration of Fantesy and Ase ${ }^{1}$

\section{TABL 5}

Mean ilaborateness and Duration Scores

\begin{tabular}{lcl}
\hline Age Groups & $\begin{array}{l}\text { Kean } \\
\text { itaboratenoss } \\
\text { Scoros }\end{array}$ & $\begin{array}{l}\text { Mean } \\
\text { Duration } \\
\text { Sooros }\end{array}$ \\
\hline $1(8-9)$ & 0.40 & 0.80 \\
$2(10-11)$ & 0.80 & 1.30 \\
$3(12-13)$ & 0.90 & 1.80 \\
$4(14-15)$ & 0.50 & 0.85 \\
$5(16-17)$ & 0.75 & 1.35 \\
\hline $1(8-9)$ & 0.80 & 1.10 \\
$2(10-11)$ & 1.65 & 2.00 \\
$3(12-13)$ & 1.40 & 2.00 \\
$4(14-15)$ & 1.25 & 1.80 \\
$5(16-17)$ & 0.80 & 1.10 \\
\hline
\end{tabular}

${ }^{1}$ A paramotyle statiotic has been enployed to test the hypothesi. regerding the relationshlp between elaborateness and duration of fantagy and age. The roason for this is that no nomparametrio statistic is avaliable for determining whother the relationship botwoen two rarlables is curvilinear. While the variables of elaborateness and duration are, in all probabil1ty, meesured in a subinterval type scale, pepers by Galto $(1959,1960)$ and others (Boneau, 1961, Keapthorne, 1955, Loxd, 1953) etrongly sugsest that probability statements dorivod from the application of parametrio statistical tests are little affected by the cholce of a scalo of measurent for analysis. 
Mean Haborateness and duration scores for each age group on the axm-levitation and selective annesia eusgestions are roported in Table 5, and show graphically in Figure 1. As indicated, both the elaborateness and duration of fantasy in rosponse to the arm-leritation suggestion axe lowoat at the ages of 8 to 9. Hes to a peak at the ages of 12 to 13 , and decline thereafter. A sinflar age trend is shom for elaboxateness and duration of fantasy in rosponse to the seleotive annesia suggestion. It should be noted, however, that the peak occurs at a sonewhat earliex age, around the jears of 10 to 11. 


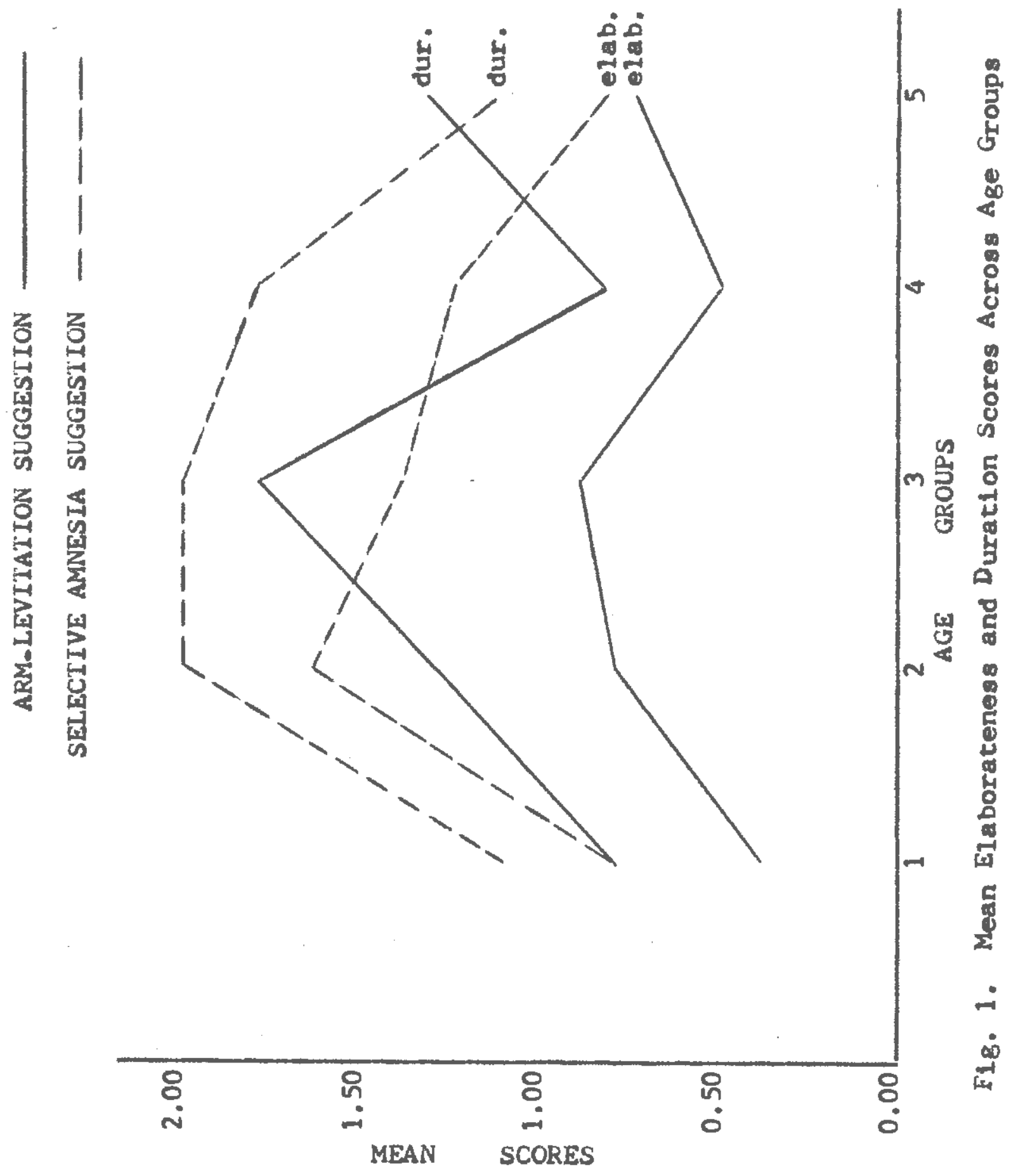


Corralation rat1os were computed to determine whether there was a signiflcant curvilinear rolationshlp between these dimensions of fantasy response and ege. These analyses indlested that only one of the relationships was signifleant. A signifleant positive relationship was found between the alaborateness of fantasy in response to the selective amnesia suggestion and age (B=.31. $F=2.61$, df $4.95, p<.05)$. Moreover, this relationship was found to be significantly nonlinear $(\mathrm{F}-2.76, \mathrm{df}=3,95, \mathrm{p}<.05)$. The reasining relationships, while in the ane direction, were indicated to be nonsigniflcant, that is, there is a positive but nonolgniflcant relationship between a) both eleborateness and duration of fantesy response to the am-levitation suggestion and age (E- .27. F-1.90, df 4,95, $p<.13)$, and b) duxation of fantesy in response to the selective amnesia suggestion and age $(e=.28, F=2.14$, df 4.95 , $p^{<-10) . ~}$ 


\section{DISCUSSION}

Hypothesis \# 1. Hithin each age groure subjects who pass each of the suggestions will tend to report engaging in goal-directed fantasy, whereas those who do not respond w1l be less $11 \mathrm{kel}$ to engage in this pattern of imaginative responding. Before preceeding to the discussion of results relating to this hypothesis, It would appear to be worthwhile to brlefly reconsider the flindings from which 1 was drawn.

In general, studies focusing on the relationship between goeldirected fantasy and the tendency to pass suggestions traditionally associated with the term hypnosis have been conducted along two 11nes.

The flrst approsch has consisted of assessing the relationship between engaging in spontaneously devised fantasy and the tendency to pass or fall suggest1ons. In his f1rst study. Spanos (1971) demonstrated that subjects who pass several types of suggestions tend to report goel-directed fantasy and that those who fall them do not report such strategy. Since then, a number of other studies have replicated this relation (Barber \& Spanos, 1972, Buckner, 1974, Spanos, 1973, Spanos \& Har, 1973, Spanos, Spillane \& MaPeake, 1974 ).

In contrast, the second investigative approach has entailed the comparison of the extent to which an expllcit strategy for Imagining is provided by a suggestion and subjects' responsiveness. For example, Coe, et 2l. (1974) counted the number of speciflc words and modifiers in a serles of suggestions that would lead 
subjeots to engage in goal-directed fantasy. They found a direct relationship between the degree to which a auggestion contaling such materiel, and subjects " tendoncy to report goal-directed fantasy and successfully respond to the suggestion. Other studies have directly manipulated the presence or absance of an expllatt Boal-direoted fantasy in suggestions for aria-levitation, aricatalepsy, ameola, and analgesia (Chaves Barber, 1974, Spanos \& Burber, 1972, Spanos, Horton, Chaves, In prese, Spanos, Sp1llane, MoPeake, 1974). In each the eame conclusion was reached suggestions whioh provide task-rolevant fantasy are nore read1y experienoed than suggeations that do not provide suoh fantasy.

Thue, severel studies enploying different methods and suggestlons under various conditions (1.0., both hypnotic and nonhypnotic) have consistently shown that goal-direated fantesy functions as a cognit1ve etrategy enhanoing response to suggestion. However, this research, like nost peychologlcal researoh, has tested subjects drawn from a ruther restricted population - students between the ages of 18 and 27 . One purpose of the present study was to deternine whether these findings could be extended to subJects frcm lower age levals (1.0., subjects botween the ages of 8 and 17).

As predicted, Irrespective of age, subjects who responded succesafully to the arm-levitation and/or solective annesia suggestion typically roported spontanoously dovising and camying out a goal-directed fantasy. whereas those who falled to respond usually 
reported engaging in some other pattern of activity. Of equal inportance, the content of subjects" testimony was remarkably sinilar to that reported in previous investigations. For example. Spanoe and his assoclates (Spanos, 1971, 1973; Spanos Hem, 1973; Spanos, Sp1llane, \& McPeake, 1974) found thet subjects exhlbited annesia for a nursery shyme or the number four when they falled to risurize this naterial wile attempting to rocite or count. In the prosent study, thls type of strategy was also employed by alnost all of the subjects who passed the select1ve amoela suggest1on. Sinflarly. thls investigator and othere have found the falling of a suggestion to be essociated with elther a) a lack of motivetion to cooperate, b) the 1nablity to adopt a make-belleve oxlentation, or c) the inability to maintain a task-rolevant fantasy. Thus, it seons reasonable to conclude that across a considerable age range, engaging in and waintaining a goal-directed fantesy faollitates rosponse to a vaxlety of suggestions.

Hypothesis \# 21 Hithin egch ege group. eubjects who pase each suggegtion w117 report engeging in goal-directed fantesies that are rore elaborate and of longer duration than those of oubjects no feil the sugsestions.

While it is olear that mereily engaging in goal-dirocted fantasy enhanoes reeponsiveness, a number of theorlsts have suggested thet the extont to which subjects becowe abeorbed or Involved in such fantasy may also bo an important vardable in determining response to suggestion. Thus, Sarbin and Coe (1972) have proposed 
the likelihood of responding successfully to the suggestion, b) the exteut to which the responee is experlenoed as an Involuntary occurrence, c) the degree to which the lmaglnings are deflned as real events, and d) the 11kelihood of passing more difflcult suggestions. These flndings are complimented by those of As (1962). J. H1lgard (1970), and Tellegan and Atkinson (1974), Indicating that hypnot10 susceptibility may be predicted from degreo of Inaginat1ve involvement in act1vit1es outside the hypnot1c situation.

Two aspects of 1nvolvemeat in suggestion-ralated Imaginings, as oonceptual1zed by Spenos and Berber (1974), wero assessed in the present study-alaborateness and duration of fantasy. As prodicted. flndings regarding the relation between imaginetive involvement and response to susgestion were replicated and extended to subjects from lower age 1evels. Irrespective of age, subjects who pessed suggestions for arn-levitation and selective amesia reported fantagles that were signiflcantly more elaborate and of longer durat1on than those of subjects who falled these suggestions. This flnding 18 reinforced by two additional appects of the data. First, as noted earlier in the discussion, subjects who fatled to successfully respond but reported angeging in goel-directed fantasy indicated, for the most part, that they were unable to 1 gnore contradictory inforration and malntaln thelr fantasy, Second, Spanos, Sp111ane, and Mopeake (1974) deronstrated that when eubjects are provided with goeldirected fantasy as a strategy, they tand to become more involved 
In responding to the suggestion and are more likely to experience the suggested effeots than are subjects not provided with a strategy. In the present study, data from the arm-catalepsy suggestion could not be anslyzed because almost all of the subfects passed 1t. This suggestion, unlike the other two, provided an explicit goel-directed fantasy as a strategy. Taken together, there seens to be strons support for the notion that involvement in suggestion-related imaginIngs 18 an important factor in deternining response to suggestion at all age levels.

Hypothesis \# 3, Ther is a curvilinear relationship between the elaborateness and duration of cog1-directed fantasy and ace.

As will be recalled from an oarlier section in this roport, studies have repeatedly shown suggestibility to rise to a peak during early adolescence and to deallne thereafter. Recently, J. Hilgard (1970) proposed an explanation for this developmental trend besed on the concept of Imaginative involvement. Speciflcally, she tas suggested that,

$$
\begin{aligned}
& \text { "...The conditions of 1ncreasing rational sophis- } \\
& \text { tication and the needs for competency and achieve- } \\
& \text { ment bring with them a decline in wonderment, } \\
& \text { these changes with age somehow counteract the } \\
& \text { 1maglnative involvements so important in hypnosls } \\
& \text { and subst1tute for them interactions on a real1ty } \\
& \text { level that makes hypnosis increasingly difflcult" } \\
& \text { (p. 189). }
\end{aligned}
$$


While the developnental 11terature relating to free fantasylike activity Indicates that J. Hligard's hypothesis is plauslble, prior to this 1nvestigetion, no direct test had been attempted.

The prediction regerding the rolationshtp between involvement in suggestion-related Imaginings and age recelved only partial support in the present study. Age tronds in elaborateness and duration of fantasy in response to both the axit-Ievitation and selective annesia suggestion were consistent with those reported for responsiveness to suggestion; that 1s, these scores were characteristically low for the youngest subjecta, rose to a peak around the ages of 10 to 12, and declined thereafter. However, correlational analysis indicated that only for elaborateness of fantasy in response to the selective amesla suggestion was there a sleniflcant curvilinear rolation with age. The remalning relationshlps, while in the same direction, did not achleve conventional lovels of signiflcance. Thus, no deflnitive statement can be made regarding developinental trends in Inafinative involvement and its relation to changes in responsiveness. However, further research along these lines does seen to be warranted in IIght of the internal consistency of the data and the fact thet elaborateness and duretion measures reached their peak within the sare age range previously dewonstrated for response to suggeation. Tho conslderations whloh nay prove to be of value in this work inoludes 1) Exasining varlations acrose one-year mer than two year age groups. Previous studies have demonstfated signiflcant changes in susgestibility using muliple-year age groups. However, 
it appeare that this technique may have the effect of masking real and significant differences between ages within these groups.

2) inploylng a larger battery of test suggestiors. Studies examining developmental trends in suggestibility have typically enployed 8- to 12-1ten scales and roport changes in terms of total scale scores. It is therefore possibie that findings of differences acrosi ages reflect variations in only a few, rather than all, suggestions. 
APPENDICES 


\section{APPITDIX A}

Form Letter Requesting Participation

\section{Dear Farent,}

I am Piartin Ham, a graduate student in psychology at the InIversity of Rhode Island. Currently. I an conducting a Master's thesis study which is concerned with the development of inaginative behavior. In order to complote this vork, it is neceseary for ne to test a fairly large number of 1ndividuals between the ages of elght to seventeen. I would very much appreclate it if you would permit your son or daughter to take part in this study. Testing w1I take place at the school during regular school hours and w111 only require approximately twenty minutes. Durlng this time, your son or daughter w11 be asked no personel quest1ons and all finding w1I remain confldential. By Igning the attached pormission slip. you w11 allow we to plece your son or daughter's neme into a pool along with those cthers who have recelved permission. From this pool the necesany number of Individuals will be selected at fandom. Please return the consent slip to the llain Offlce.

Thank you for your time and consideration.

I heroby give my consent for

to participate in a stuiy conducted by Martin Hain at (name of school).

Date of B1xth

Parent

Stuily Perlods

Date

THSTING WILL BE DONE IN THE CONFERENCE ROON IN THE VAIN OFFICD. 


\section{Appendix B \\ Manual for Soorlng Goal-Directed Fantasy ${ }^{2}$}

The purpose of this manual is to teach individuals to score the verbal testimony of subjects admintstered test suggestions for the preaence of goal-directed fantasy. As raters you will be presented with the verbal transactions of an experimenter and his subjects, and you will be asked to indicate whether or not the trensaction indicates that the subject engaged in a pattern of activity labeled goel-directed fantasy. The experimenter-subject transactions you w111 be asked to rate were gathered in a study which possessed the following character1at1cs. (a) Subjects vere adninistered 1deo-motor suggestions, challenge suggestions, and an amnesla suggestion. (b) After they had responded to each suggestion, subjects were asked to report what had been passing through their minds while they had been responding to the suggestion. (c) After the subject reported what had been passIng through his alnd the experimenter often asked him to elaborate on his answers.

As raters you will be presented with separate pleces of paper one plece at a time. Each plece of paper contains the verbal transaction which occured between the experimenter and a subject after the subject had responded to a single test suggestion. Thus each plece of paper contalns a subject's verbal response to the experimenter's request that he (the subject) report what was passing through his

Thls manual was constructed by Dr. N.P. Spanos of the Medfleld Foundation and has boen included varbatin in this roport with his knowledge and pernission. 
uind whlle he was responding to the test suggestion. Fich plece of paper also contalns all further questions asked by the experinenter about the subject's response to the partioular auggestion, and all of the subject's verbal rosponses to these questions by the experimenter. Fach plece of paper is to be rated soparately for the prosence or abgence of goel-directed fantasy.

\section{Defining Characteristios of Goal-Directed Fantasy}

A subject is to be judged as having engaged in goal-directed fantesy if the verbel transaction between experlementer and subject inalcates that the subject created in fantasy or 1magingtion a eituation which, If it were to occur in the "objective" world, would be expected by the subject to produce the behavior oalled for by the test susgest1on. For example, if a heavy brick were to be placed on top of a subject's outstretched arm, the arm would feel heavy and would be lowered by the relght of the brick. Thus, a subject adminlstered a test suggestion of am lowering would be scored as engaging in goaldirected fantasy if he stated that. while responding to the susgestion, he Imaglned that a heavy brick had been placed on his arm. However, a subject who stated that he lowered his arm simply because it became heary, and further indicated that it became heary simply because 1t was outstretched, would not be scored as having engaged in goaldirected fantasy. The latter subject simply reported what was objectively true, that 1s, an outstretched axm will become heavy if it romains outstretched. The subject did not construct in fantesy a stuation which, if it were "real" would lead to his arm becoming hoary. 
The following experfmenter-subject transaction is one indicating that the subject employed goal-directed fantagy. A subject administered the subgestion that he would be uneble to stand up from his chair roports!

S. There were ropes tying we to the chair so I couldn't stand. E. Could you see the ropes, in your mind I mean?

S. Nio. I couldn't see then really, it was more like I could feel then. I felt like I was tied.

ए. You didn't have a mental ploture of yourself being tied to the chatr?

S. It waen"t a plcture exactly. I knew there were the ropes, I could feel them pressing agalnst me when I trled to move, but I don"t think I had any piotures.

The above excerpt is scored as evidencing goel-directed fantasy despite the fact that the subject denied engaging in visual imagery. It is important for the rater not to identify the terms fantrsy and imagination with visual 1magery. Fantasy can occur in the abeence of visual 1nagery. The above example is scored as Indicating goal-directed fantagy because the subject gave evidence of having constructed in iragination (but in this case without the use of visual inagery) a atuation which, if it were to really occur, would prevent him frow standing up.

The rater must keep in mind that the subject may ongage in fantasy that is not goal-directed. Such responses are scored as not exhlbiting gosl-directed fantasy. The following is an example of 
fantasy which is not goal-directed. A subject adminlstered the susgestion that his outstretched ams rowld move apart reports:

S. I could Imaglne my amis, and then I just saw then begin to move apart.

E. You saw then?

S. In my mind, I saw them, they just started to move.

E. DAd you 1magine enything else, anything in relation to your arms noving?

s. No, nothing else.

E. Just your arns moving?

S. Yes.

The above transaction is scored as not indlcating goal-directed fantasy because the subject did not create an 1maglnary situation which. If it were real. would cause his arms to move apart. Had the subject stated that he Imagined a force acting on his hands to move them apart then, the transaction would have indlcated goal-directed fantasy.

It is important to point out that goal-directed fantesy need not involve imaginary situations which actually could occur or which necessarly have a high probablity of occurrins in the real world. Instead, the 1maginary situations must be such that if, for some reason $1 t$ were to oscur in the objective world. it would be expected to lead to the bahavior called for by the test suggestion. The following is an example of goal-directed fantasy which cowld not occur in the objective world. However, if the objective world were 
to somehow change so that the eventa to be described did occur, then the behavior Implied by the following tes. suggestion would be expected. A subject told that he would be unable to bend his outstretched am reports.

S. I could see my arm clearly in my mind. I was holding it out straight, but it got etrange and started to chenge.

E. How dis it start to change?

S. Well, Ito funny, but it beceme steal, I1ke ny arm turned into steel.

1i. Could you tmagine it clearly?

S. I could see 1t, it was steal, a long plece of steal, my arn became steel.

The above described set of events obviously could not occur in the real world. That is, In the objective world, one's arm never turns into a plece of steel. Honotineless, responses such as the one above are scored as exh1blting goal-directed fantasy because the situation described, if it were for some reason (however far-fetched) to occur. would be expented to lead to the behavior Implied by the test suggest1on.

It is important for the rater to realize that reports of goeIdirected fantasy may constitute oniy a part of the response emitted by the subject. The subject may also state a great doal nore which Is unrelated to the presence or absence of goal-directed fantasy. In such cases the transaction should bo rated as indicating goaldirected fantasy despite the fact that the subject's response conslats of other components as well. The following is an example 
of a transaction which includes not only goal-directed fantasy but other responses as well. A subject told that he would be unable to stand up from his chalr reports:

S. When you first told me I couldn't stand up I wasn"t sure whether I could or not. I sort of tried to tell myself that I couldn't stand.

D. Shat was passine through your mind at the time?

S. That I wanted to please you, and that I knew that I wasn't supposed to stand up.

F. Were you inagining or pleturing anything?

5. Yes. I could see myself tied to the chalr with heavy chalns. This kept me from standing up.

The above transaction would be scored as indlcat1ng goal-directed fantasy regardless of the fact that there were other important components to the response.

Cccasionally, subjects will engage in goal-directed fantasy, then shift from this fantasy frame of reference to an objective frame of reference and, then, while operating from the objective fxame of reference deny the reality of their fantasy. Such responses should be scored as exh1biting goal-directed fantasy and should be distingulshed from fantasy that is not goel-directed. The following is an exarple of moal-directed fantasy which the subject himself negates while operating from an "objective" perspective. A subject told he would be unable to stand up from his chalr reports:

S. I could see myself tied tightly to the chalr.

ज. Then why did you get up? 
S. Well. I knew it was all in my inagination, when 1 t oane time to got up I know I man't roally atuok.

The above subject angaged in goal-directed fantasy and should be scored as having done so despite the fact that he also gave evidence of having changed his perspective to a fzomework whlch negated the reality of his fantesy. Th1s type of reponse should bo distinguished from the rosponse of a subject who maintains a fantasy that is not goal-dirocted (0.g., I lmaglned ny arwo noving apart). The former subject should be scorod as having ongeged in goal-directed fantesy. the latter should not.

Occasionally subjects responding to challenge suggestions initially exhibit a gon-directed fantasy but then ohange the contents of the1r fantagy to an Imaginary atuation whloh is no longer goal-direoted. For example, a subject told that he 1t atuok to his chalr respondsi S. I was tied to the chalr, there were ropes around ay body.

E. Could you see the ropes clearly?

S. Vory clearly.

E. thy did you stand up?

S. When I tried to stand they broke and I wes able to get up.

Subjects who repond in this way should be scored as exhlbiting goal-directed fantagy despite the fact that the contents of their fantasy changed.

The reaponse of a aubject who engages in goal-dirocted fantasy should aleo be distinguished from the response of a subject who fails in an attempt to engage in goal-directed fantasy. For exnmple, a aubject told that he would be umable to stand from hls chalr reports 
S. I tried to thlak that I was t1ed to the chair, but I just couldn"t do 1t. It's Imposible to Imagine that.

The above subject should be scorvd os not having engeged in goalalrocted fantasy despite the fect that he presumably ade some attenpt to engage in such a response.

Thus far we have dealt with the charecteristios of goal-directed fantasy given in response to ideo-rotor and challenge suggestions. Subjects rero also asked to fonget the number 4. Subjects passed this suggeation if they counted fros 1 to 5 without gaylng 4 . Subjects should be scorod as angaging in goal-dirocted fantasy in reoponse to the ameata auggestion if they roport the occurrence of a set of fantesy events which offectively eliminate their thoughts, and inages of the number 4. The folloulng 18 an example of goal-directed fantasy given by a subject told to forget the number 4.

5. Whan you asked me to forgot the number 4, at flret I didn't know what to do. I Just kept thinktng of 4.

E. What did you do?

S. Well I plotured the numbers, you know, In $\mathrm{my}$ aind, and then this boul owe along and it covered the number 4.

E. Why didn't rou sey the number 4 ?

S. Because it men't there.

Another example of goal-d1rected fantesy in rosponse to the annesie suggestion le seen below.

S. Well, I plotured this clook in my mind, with all of the numbers around in a ofrcle, but the four wan't thero. 


\section{E. Where wes 1t?}

S. I don't know. There was just this space where the 4 should be. As wth fantasy responses to 1deo-wotor and challengo suggestiona, all fantasy responses to the amnesia suggestions need not constitute Boal-directed fantasy. The folloring represents a fantasy response to the anneale suggestions that is not goal-directed.

S. I pletured each of the numbers on a wooden block, and then I sar the 4 block fade into the beckground.

E. Then why did you sey 4 ?

S. I don't know, I guess I could at1ll nomomber 1 t.

E. IId you try to forget the 4 ?

S. Yos, I trled, but the 4 block nover faded away completely. I could alvays see 1t, even though it was dimer than the otherw. The following 18 also an exanple of a rosponse to the annesia susgestion which does not involve goel-directed fantasy.

E. What was passing through your aind when I suggested you forgot the number 4 ?

S. Hell, I counted the numbers 1 through 5 and okippod saylng the 4. In $\mathrm{my}$ ind that is.

E. When I asked you to count out loud, why did you say 4 ?

S. Beosuse I didn't really forget 1t. When I skipped 4 I know I hadn't forgotten 1 t.

The above rusponse should be scored as not exhl hitlins goal-directed fantasy bocause it indicates that the subjact was aure of the number 4 but simply shoped saylng it while counting to himself. He oreated a situation which led to aldpping but remenbering the number 4 . He did not oroate in Inagination a situation which affectivoly eliminated the number 4 . 
IF' THE RATER HAS ANY QUESTIONS HE SHOLLD ASK THEY NOW.

\section{Instruct1ons}

The contents of each iter with which you will be presented is to be juiged for the prosence or absence of goal-directed fantasy. You are to Judge the contents of each 1ten, one 1tan at a tine. Do not Iot the judgrents aade in any one case influence any future judgments. Whon jou receive the 1to you are to juige road it carefully Beveral tines koopling in wind the crterla for goel-direoted fantesy outlinad in the sanual. You may rofor to the manual for alarficetion at any timo and should do so whenover nocesary. You aro to ake only a aingle dicotcans mating for each 1ten. That is, in enoh case you are to judge whether or not the subject engaged in goaldinoted fantasy. Pate eioh 1ter in the order presented to you. Do not aldp rating any 1tem. If you find an 1ten particulerly difficult to mate even after roferring beok to the manual, nake the best judigment jou can, but do not skip the 1tem. You w1Il juige 28 itens. The 1tcas are nutbered 1 through 28 , You w1ll bo presented with a rt1ng shest also numbered 1 through 28 . The numbers on the rating sheet corrospond to the numbers on the 1tens. Do not maxk the 1teans thenselves, 1nsteed, nake each rat1ng on the rating sheot. 


\section{Appendix C}

Manual for Scoring Elaborateness of Suggestion-Related Imaginings

This manual is designed to teach individuals how to rate the - laborateness of subjocts' tastimony for goal-directed fantasy in rosponse to suggestions. As reters, you will f1rst 11sten to tape-recorded verbal interchanges between an expeximenter and a subject. These interchanges wero obtained in a study in which subjecte wero adninistered three types of suggestions--an 1deomotor suggestion, a challenge suggestion, and an anesia suggestion. Inmediately after monding to each of these suegestions, subjocts were asked to describe the plotures, images, and thoughts thoy experienced while responding to the suggestion. After carefully listening to this testimony, it is your task to indicate the elaborateness of oach roported pattern of Imagining by assigning a soore of olther $0,1,2$, or 3 . In so dolng, It Is assumed that you have a cloar understanding of the cheracteristics of gool-direoted fantasy as described in the Maning for Scoring Goel-Directed Fantasy (Spanos, 1971). If this is not tho case, pleese consult this manual before resding further.

\section{Criterla for Pating F1rst Vorkel Interchange}

The first suggestion administerod to each subject was for armlovitation and was worded in the following anner!

Hold your right arm stralght out in front of you. Inegine that the ard is booning lighter and lighter, that it's moving up and up. It's wolghtloss and rising in the air. It's lighter and Ilghter, Fing and l1fting more and more. It's lightor 
and Iighter and moving up and up. It's moving up and up. more and more. It's lighter and 11ghter, moving up and up, more and more, hlgher and higher.

Following his response to this suggestion, the subject was asked to describe what he had experienced.

Asslgruent of a rating of "0." This testimony should be given a Iating of " 0 " If the subject does not Indicate that he ongaged in goaldirected fantasy that 18, if the subject falie to roport inagining atluation which, if it were sotully to occur, would produce the arlevttation response. Thus, a subject should be aselgned a score of "O" If his teatimony includes statements such as (a) I didn't raise my arin because I didn't want to, and (b) My arn didn't feel light but I rased 1t because I vanted to cooperate and help out the experdFint. This does not mean, however, that only those subjects who fall to engage in fantasy should recel ve a score of "O." A subject may angage in fantasy that is not goal-dirsoted. Such a rosponse chould also be scored as " 0 ." The following 18 an examle of this type of fantasy report:

S. I Inaglned my arm and I waw $1 t$ beginning to rise.

E. You waw your am?

5. Yes, I sew it in my mind. It was noving up rery slowlya

F. ILd you pleture anything else?

S. No

Ausfgment of a rat1ng of " 1 ." A rating of $1{ }^{\text {" }}$ should be assigned if the eubject indicates in his testinony that ho employed a besic 
cognitive strategy that enabled him to experience the suggested offect, that 18, the subject reports Imegining a speciflc situation, which, if It were actually to occur, wovld cause his arm to Hse. Thus, testimony such as the following should be scored as " 1 "

I plcturod these balloors, hellum fllled balloons, they wore tied to my wist. I tried to hold ny arn down but I courdn"t.

The balloons just kept pulling ny arm up higher and higher. Sinilarly, a rating of " ${ }^{\prime \prime}$ should also be assigned to reports such 288

I Imagined that my arm was hollow and somebody was putting alr into 1t, that my arm was hollow, there was nothing in It and somebody was putting air into 1t. Assignment of a rating of "2." It 18 important to note, that whlle the fantasy reports scored as " 1 " include a basic stratesy for experiencing the suggested effect, the strategy is carriod out in 1solation; that 18, it is not placed uthin a broader and more elaborate Inagined context. If a subject's testinony Includes a basic strategy carried out within an elaborate Inagined context, a scure of " 2 " should be assigned, that 1E, if the subject reports a strategy in an elaborated context which goes beyond that necesany for simply experienang the susgested effect. Accozdingly, the following subject-exper1menter transection would recolve a rating of "2:"

s. My hand felt really gtrange. It was liks it was a balloon, the kind you fl11 wth hellum.

E. Tell me more. 
5. My hand felt really light and 1t began to float up into the alr. It just kept floating up higher and higher unt1l 1t lifted we off the ground.

E. Anything else?

S. I lagafined myself being pulled up into the alr by ny hand. I could seo lange white clouds all around we and when I looked down, the people and bulldings looked very emall, 11ke I was up really high.

\section{Griteria for Rating Second Verbel Interabange}

The second suggestion that was adrinistered to each subject wes the following arm-catelepsy suggestion,

Hold your left am tralght out in front of you. Inagine that your an is in a cast so that the elbow cannot bend. Iragine that the cast makes the arm stiff, FlgId, and Imovm able, It keeps the elbor from bending. Your an cannot bend, It's held tightly by the cest, stiff and Ifld, so otiff and Ingld thet 1t won't bend no matter how haxd you try. It's atlff and Ifgid, stiff and Ifgtd, hold tightly by the cast. The more you try to bend 1t, the etiffer $1 t$ will become. You won't be able to bend it until you hear ny flngers snap. Again, the subject was asked to descrtbo the ploturos, Images, and thoughts he experienced while responding to the suggestion. Asalgment of a rating of "O." As bofore, the subject whose testimony indicetes that he elthor did not ongage in fantesy activity or 
engaged in fantasy that was not gool-directed should be assigned a score of "0." Thus, traneactions should be rated as " 0 " 1 they include staterents such as (a) I jidn't try to bend my arm, (b) I didn't 1magine anything. I just concentrated on keeplng my am as stiff and rigld as posstble; or (c) All I laagined as ny ara and it felt very very stiff-Nothing else.

Asolonment of a rating of "1." Unlike the am-levitation auggest1on, the suggestion for ax-catalepsy prosents the subject whth a specifle technique or strategy that will enable him to experlence the suggested effect, that 19, the suggestion alks the subject to iargine a speciflc situsion (a cast on his ard) which, if it were the actud atate of affalcs, would prevent int from bending his ars. If a subject" s tastimony indicates that he exployed the cognitive strategy provided by the auggestion but falled to elaborate on 1t, a soore of " 1 " should be assigned. The following experinenter-subject transaction is cne meoting these criterial

S. I Inagined ny an stralght out in front of go and ny ane was rrapped in a cast.

E. Can you tell we nore?

S. My an felt 11ko it wos in this cast. It folt stiff and Ifld I1ke I couldn't bend it.

E. What were you inagining?

S. Just the cest on my aril and how I wouldn"t be able to bond 1 .

E. Anything else?

S. No, nothing else. 
This interchange is rated as " 1 " because the subject enployed the strategy prosented by the suggestion but did not add anything to 1 . Ase1gament or a zating of "2." Two types of fantasy repurts should receive a rating of "2." The first is one in which the subject Indicates that be employed the strategy presented by the suggsetion and expanded on 1t to some extent; that 18, the subject states that he Imagined a cast on h1s arm and goes on to describe it with adjoctives not included in the oxiginal suggestion. The following is an example of testimony of this types

S. My axw was stiff and I couldn't bend it until I got my cast off.

E. Can you tell we more?

S. I was nervous. I had a cast on. It had names written on It and everything.

E. Waht wero you Imagining?

S. A white cast on ay arm. It had writing on 1t and it wes in a sling.

E. Anything else?

S. I didn't I1ke my arm being in a cast. The second type of testimony that should be rated as " 2 " 18 one in which the subject indicates that he totally disragarded the auggested stratery and instead construoted a unlque goal-dirooted fantasy. For example, the following report indicates a fantasy situation quite different from that suggested 
It was really heavy. Ify an was really heavy and I wanted to berd $1 t$ and put $1 t$ down but I couldn't. It felt like my arm was a big metel rat. It had hinges on it but they were all fusty. It just wouldn"t bend. Along similar 11nes, reports that include statements such as $\mathrm{fy}$ arm felt like it was a plece of wood, I 1maglned that my arm was welded to a plece of steel, or, It felt $21 \mathrm{ke}$ some force was pressing on $\mathrm{ry}$ arm, should also be scored as "2." It 18 important to note, that the extent to which the subject describes his 1deosymcratic strategy may be lese but not greater than thet necessary to assign this score to a fantasy production based on the suggegted strategy.

ABgignment of a rating of "2." There are two orfterla which nust be mot in order for a subject's testlmony to be assigned a reting of "3." These are: (a) It must indicate that the subject employed a basic strategy (elther sugsested or 1deosymcratic) that enabled hin to experlence the sugested effect, and (b) It must further indicate that the subject carrled out this basic strategy within a broader and wore elaborste lagined context. The following fantasy productions, based on the suggested atrategy, neet these crlterla,

Subject 11. I pletured a cast on my ami and felt 11 ke 1t was heary. I was kind of scared and I felt like I was in a hospital. I was laylng In a bed in the hospltal and I couldn't wove ny arm it was very atiff and 1t hurt. It kind of felt l1ke 1t was stiff and it felt so heary that I couldn't bend 1t. It felt very very stiff. subject \#2. I thought that I was on a doctor"s chalr and ho was sawIng it (the cast) with a saw, taking it off. My arm wes tired and I thought it would hurt when the doctor saved it off. 
S1ullarly, the followlng fantasy, in which a unique strategy was erployed, also meets these criterias

5. I Imagined that this big steel bar was attached to my arm so I couldn't bend $1 t$.

E. Tell me nore.

5. At flrst I saw ny and and this bar next to 1t. Then soneone plcked up the bar and started walding it to my arn so I wouldn"t be able to bend 1 .

E. Anything else?

S. It was really strenge. I could soe the sparics and everything but 1t didn't hurt. My arm didn't feel anything.

Each of the fantasy reports cited above ahould be rated as "3" because they not only include delinitod patterns of lmaglning that are directly related to the afin of the suggestion, but also numerous associative elaborations consistent with this ain. Criteria for Rat1nx Thind Verbel Interchange

The final verbal interchange to be rated will contain testinony regarding the subject's experlences while reopond1ng to a suggestion fer annesia for the number four. This suggestion was worted in the following manners

I want you to forget the number four. I want you to wipe the number completely fran your wind so that you are unable to think of, rooall, or remenber the number four in any way. The number foux will be gone completely from your mind. You"1l be unable to think of, recall, or remeanber this number 
In any way unt1l I 1nstruct you to remember it.

Asgigment of a rating of "O." As before, an experdmenter-subject transaction should be assigned a score of " $0 "$ if it indicates that the subject elther (a) did not see the situation as one in which he was to cooperate in atteipting to pass the suegestion, or (b) was motivated to cooperate but falled to engage in goal-directed fantasy. The followIng are examples of this type of testimony:

Subject \#1. When you told me thet I'd forget the number four I Immediately began to flght it in ay nind. I thought it was silly. I know you couldn't make me forgot the number just by telling me to forget 1t. So when you sald to forget 1t, I began telling myself I could nomober. I rept saylng the number in ny mind over and over. Subject $\# 2$. It seens like the nore I trled to forget the number the more I ranembered 1t. E. How did you go about trylng to forget?

S. I fust kept saylng to myrelf, "You'2I forget four, you'll forget four," and it just didn't work.

Assigment of a reting of 1." If the subject reports a fantasy production in wich only the absence of the number four 1s 1naged, a score of " $1 "$ should be given, that 1s, this rating should be assigned if the number four is never present in the fantasy. Thus, a statewent such as. I plotured in my mind numbers and there was a whole ino of them and there wasn't any number four there, would fall into this category.

Assignment of a rating of "2." In contrast to the above, a subject"s testinony should recelve a rating of " 2 " if it indicates that 
an imaginary situation was constructed in which the number four (or some symbollc representation of 1t) becomes absent. More specif1cally, the subject reports a fantasy in which the number four or a ropresentation of 1t is 1nftially present and then, for some unexFlained reason, dissppears. Fror example, a score of "2" should be assigned if the subject indicates that the number four vanished, disintegrated, floated asay, etc., but fails to provido any reason for the occurrence of these events. The following is typlcal of this type of transact1on:

S. When you said to forgat the number four, I f1rst pictured the number one through flve in my mind. Then 1 t all foll apart.

E. What all fell apart?

S. The number four.

J. Why d1d it fall apart?

S. I don't know, it just disintegrated. It just wasn't there any more.

Assignment of a rating of "3." If the subject reports ongaging in an elaborate fantasy, that Includes both the disapperrance of the numbor four and a reason for its disappearance, a score of "3" should bo assigned. The following testimony represents this type of fantasy production,

S. I pleturod in my mind a blackboard that was writton one through five, and I plcked up an eraser and knocked off the number four. Then I kept counting one, tro, three, flve... one, two, three, flve, t1ll I wh sure there was no number four. I. Why didn"t you say the number four while counting? 
S. Because I orased it off the biackboand and didn't ramenber 1t... on the board in my brala.

The following is also an example of a response that should rocelve

a rating of " $3, "$

8. I plotured each of the numbers on a wooden block and then I say someone reach out and take away the one with the number four on 1t.

B. tho took 1t away?

3. I don"t know. I fust sav this hand reach out and take away the block with the number four on 1 .

IF THE RATER HAS ANY QUESTIONS HE SHOULD ASK THEM NOH. 
VII

REFFERENCES

Ames, I. B. Chlldron's storles. Gonetic Psycholosy Monosraphs, 1966. 73. $337-396$.

Andorson, M.L. Correlates of hypnot1c performance, An historlcal and rolo-thoorotical analysis. Dootoral dissertation, Untveralty of Callfornia, 1963.

Anderson, M.L. \& Serbin, T. Ro Base rate expectancles and motoric alterations in hyposis. Intermational Jourmal of Ginleal and Bxperimental Hypoosis, 1964, 12, 147-158.

Amold, M. B. On the wechanten of evggestion and hypnosis, Journal of Aboozal and Soctal Psycholocy, 1946, 41, 107-128.

As. A. Non-hypnotic expertences related to hypnoticablity in male and female college students. Seandinevian Journal of Psychology, 1962, 2, 112-121.

As, A., O'Hars, J.W., \& Munger, N.P. The measurenent of subjective experienees prosumably related to hypnotio suscept1bility. Scandinevian Journal of Psychology, 1962, 2, 47-64. Atkinson, G.A. Personallty and hypnotic cognition. Dootoral dissertation, Untrersity of Minnesota, 197.

Earber, T.X. Experimental orldence for a theory of hypnotic behavtors II Bxperimental contrals in hypnotic age regression. Intermational Joural of Glinical and Expertrental Hronosis. 1961, 2, 181-193. 
Barbor, T.X. "Hypnosis" as a causel verleble in present-day psychologyi A ortical analysis. Perohologleal Beports. 1964, 14. $839-842$

Barbor. T.X. Measuring "hypnot1o-11k" auggeat1bl1ty wth and wthout "hypnotic induotion," psychometrle propert1es, noms. and varlables influencing response to the Barbor Sugsestiblity Scale (BSs). Parchologleal Reporte, 1965, 16, 809-844. (a) Berbor. T.X. Physiologtenl effects of "hypnot1c suggestions,"
A critical revion of recont rasearch (1960-64). Psychologlonl Bullet1n, 1965. 63, 201-222. (b)

Barber, T.X. Hrpnosise A solent1flo approach. Ner Yorki Van Noatrand Relnhold, 1969.

Barber, T.X. Suggested ("hypnot10") bohav1or The trance paradign vorsus an alternative paradigm. In E. Fronm and R.E. Shor (Bds.) Hronosist Recearch Dorelopments end Porspeotives. Chlcago: Aldine-Atherton, 1972, Pp. 115-182.

Barbor, T.X., Calvoeles. D.S. "Hypnot1o-11ke" suggest1bility in chlldren and adults. Jompin of Aborengl and Soolal Psroholosy, 1963, 66. 589-597.

Barbor, T.X., \& Calverley, D.S. An experinontal atudy of "hypnot1c" (auditory and Visul) hallucinations. Journal of Abnormal and Soc1ar Perchology, 1964, 63, 13-20. (a)

Barber, T.X.. \& Calverley. D.S. Hypnotigablity, suggestibility, and porsonality: II Assosement of previous ingsinativefantasy exporlences by the As, Barber-Glase, and shor quest1onaires. Joumal of Glinloal Psychologx, 1964, 27. 57-58. (b) 
Barber, T.X., \& Calverley, D.S. Effects of hypnotic 1nduction, suggestion of anesthesia, and distraction on subjectivo and physiologtcel responses to pain. Paper presented at tho annual nooting of the pastern Fryohological Assoolation, PhIladelphla, April 10, 1969.

Barber, T.X., Glass, L. B. S1gniflcant factors in hypnotic behavior, Jouranl of Abnormsl and Social Payahology, 1962, 64, 222228.

Barber, T.X., \& Hahn, K.W., Jr. Phyelologlcal and subjeotivo Iesponses to pein produclng stimulation under hypnotlcallysuggested and waking-1maglned "analgesia," Joumal of Abnormal and Soctal Porchology, 1962, 65, 431-418. Barbor, T.X., \& Haln, M.W. Hypnotic Phonomens. Morristom, N.J.8 General Learning Press, 1974. Berber, T.X., Spanos, N.P., \& Chaves, J.F. "Hypnos1s," Imagination, and human potentialitiog. New Yorks Pergamon Press, 1974. Binet, A. La Suggestibilite. Par1si Scheicher Freres, 1900. Boneau, C.A. A note on measurement scalos and etetistical tests. American Psyoholog1st, 1961, 16, 160-161. Brald, J. Neurrpnology, Or the rationele of nerrous bleop congldered in mation to andmal magnotien. London, Church111, 1843. Bxamrell, M.J. Hypnotian, its history, praction and theory. Ph1ladelphila. J.B. Iippincott, 1930. Buckner, L. Goel-directed fantasy and hrpnotic susceptibility: Funotion of exieting sidil and instruction content. Masters thesis, Callfornia State Univeraity at Fresno, 1974. 
Chaves, J.F., \& Barber, T.X. Cognit1ve strateg10s, experimenter modeling, and expectation in the attenuation of pain. Journal of Abnomal Psychology, 1974, 83, 356-363.

Chertok, L., \& Krawarz, P. Hypnos1s, sleop, and electro-encephalography. Journal of Neryour and Mental Dlecase, 1959, 128, 227-238.

Coo, Woc. The houristic value of role theory and hypnosis. Doctoral d1seortation, University of California, Berkely, 1964. Coe, H.G., Allon, J.L., Krug, W.M., \& Wurraman, A.G. Goal-dirocted fantasy in hypnotic responeiveness, 5k11l, 1tem wording, or both. Intornational Journal of Clinieal and Experimental Hypnosis, 1974, 22, 157-166.

Coo, W.G., \& Sarbin, T*R. An experdmental dewonstration of hypnosis as role onactment. Jourangl of Abnorial Perobology, 1966, ㄱ. $400-405$.

Coumins, J.R., Fullam, F., \& Darber, T.X. Effects of experimenter modeling, demands for honesty, and Initial lovel of suggestibility on response to 'hypnotic' suggestion, Medfleld, Mass. s Medfleld Foundation, 1973. (Mimeo)

Cooper, I.M., \& London, P. Sex and hypnotic susceptibflity in chlldren. Internationgl Journal of Ginicel and Bxpeximentel Bingnosie, 1966, 14, 55-60.

Cooper, L.M., \& London, P. The develupment of hypnotic susceptibilitys A longltudinal (convergence) study. Child Development, 197. 42, 487-503. 
Diamond, H.J. The use of observationtly-presented inforration to modify hypnotic suscoptiblity. Journal of Abnongl Parchology. 1972. 29. 174-180.

Evans, F.J. Recent trende in experimental hypnos18. Behsvioral Sctence, 1968, 13, 477-487.

Evans, M. B. * Paul, C.I. Fffects of hypnot1cally suggested analgesia on physiologlcal and subjective responses to cold stress. Journal of Consulting and G11ntcal Psychology, 1970, 25. $362-371$.

Gaito, J. Nonparametric methods in psychological research. Parcho10810a1 Reports, 1959, 5, 115-125.

Gatto. J. Seale classiflcation and statist1os. Poxoholog len Revien. 1960, 67, $277-278$.

G1Ibert, J.A. Hesearches on the mental and phrsical development of school chtldaren. Studies of the Yale Parohologleal Laboratorles, $1894,2,40-100$.

G1roud, A. La suggest1bil1te cher des enfants d'ecole de sept a dours ans. Annee Psycholog1e. 1911, 18, 362-388.

Guid1. G. Fecherches experimentales sur la suggest1blit1e. Axchives of Parcholoty, 1908, $\underline{8}, 49-54$.

Her, M.W., \& Spanos, K.P. Suggested aulitory and visual hallucinations In task-motivated and hypnotic subjects. American Journal of Glintoal Hypnosis, 1974, 17. 94-102.

H1lgand, E.R. Altered states of awareness, Journal of Nervous and Mental Diseases, 1969, 149, 68-79. HIlgard, E.R., * Tart, C.T. Responsiveness to sugestions folloulng 
whing and Inagination instructions and following Induction of hyprosis. Journal of Abormal Psrcholosy. 1966, 21. $196-208$.

H1gard, J.R. Personal1tr and hymosis. Chloagot Culveralty of Chlcago Press, 1970.

Hilgan, J.R. Imaglnative Involvement, Sone oharacteristice of the highly hypnotizable and the non-hypnotizable. Interphtional Joumal of Clintoal and Experinental Hronosis. 1974, 22, 138-156.

Hurlock, E.B. Child development. Ner York: MoGzar-H111, 1964. Jenet, P. Parchological healing, A historlcal and clinical studr. Translated by t. and C. Peul, New York, Crowel1-Col11er and Macatlian, 1925.

Jerzild, A.T. Child psychology, 3rd ed. Nex Yoxk, Prent1oe-Hall, 1957, Jers1ld, A.T., Markey, F.V., \& Jers11d, C.L. Ch1ldren's feers, dreans, Mishes, daydreans, 11kes, dislikes, pleasant and unpleseant wemor1 es. Gh11d Development Monoseneph, 1933. No. 12.

Johnson, R.F.Q. Cognit1ve strategles and response to cold-induced pain. Paper presented at the meeting of the Southeasterm Peychological Association, Ner Orleans, ApH1 6, 1973. Kempthorne, 0 . The rendomization theory of experiaentel inference. Journal of the American Statietical Associat1on. 1955. 50. $946-967$.

Lee-Teng, E. Trence-susceptiblity, Induction-euceptiblilty, and 
acquiescence as factors in hypnotic performance, Joumal of Abnomal Psychology, 1965, 20, 383-389.

Lohnan, H.C., \& Wtty, P.A. The paychology of play getivitiog.

Ne: York, Barnes, 1927.

London, P. Dovelopwental experiments in hypnosis, Joumal of Projeot1ye Techniques of Personal1 ty Assessnent, 1965, 22. 189-199.

London, P., \& Cooper, L.M. Noms of hypnotic suscept1bil1ty in ch1leren. Devolopmental Poychology, 1969, 1, 113-124. Lord, F.M. On the statistical tratiment of football numbors. American Psychologist, 1953, 8, 750-751.

Markey, F.V. Imaginative behavior in preschool children. New Yorks Colmbia Unt versity, 1935.

Messerschn1dt. R. The suggestibility of boys and gixls between the afes of six and sixteen. Journel of Genetic Psychology, 1933, 43, 422-437.

Morgan, A* H., \& H1lgard, E. R. Age differences In susceptlbility to hispnosis. International Journal of Clinicel and Experinental Hronos1s, 1973, 221, 78-85.

Papov, E.F. Suggest1bility and autonaticism 1n school children. Prop1lak-Medets1na, 1926, 5, 68.

Flagot, J. Flay, dreans, and 1mitation In childhood. New Yorks Niorton, 1962.

P1tcher, B.G., \& Prollnger, F. Ch1ldren tell atories: An analve1s of fantasy. New York, Internat1onal Unlversitles, 1963. 
Reymert, M.I., \&ohn, H.A. An objective Investigation of suggest1 fllty. Character and Personal1ty, 1940, 2, 44-48.

Rose, E.A. Soclal Psychology. Nen Yorkt Macm1lian, 1908.

Sachs. I.B. Modification of hypnotic behavior without hypnotic Induct1on, Morgantown, H. Va., Department of Psychology, Weat VIrginia University, 1969.

Sachs, L. B. Construing hypnosis as modiflable bahaviox. In A. Jacobs L. B. Sachs (ids.). The psychology of private events. New Tork, Acaderic Press, 1972.

Sachs, L.B., \& Anderson, W.L. Modification of hypnot1c suscept1bility. International Journal of Clinical and sxperinental Hymonos1s, 1967. 15, 172-180.

Sarbin, T.R., \& Anderson, M.I. Base-rate expectancles and perceptual alterations in hypnosis. British Journal of Clinical Psychology, 1963. 2. 112-121.

Sarblin, T. R., \& Coe, W.C. Hypnosise A soolal paychologioal anal ysis of Influence communication. New York, Holt, Pinahart \& Winaton, 1972.

Sarbin, T.H., \& Juhasz, J.B. The histurlcal background of the concept of hallucination. Journal of the History of the Behavioral Sciences, 1967, 4. 339-358.

Sarbin, T.F., \& IIm, D.T. Some evldence in support of the rolotalk1 hy hypothesis in hypnosis. Intermational Joumal of Alinical and sxperimental Hronosis, 1963, 11, 98-103. 
Schneok, J.M. Obervations on hyphotio draans. Perceptual and Motor S16118, 1969, 28, 414.

Shorean, I.C. The suggestiblitity of normal and mentelly defective ch1ldron. Comparetive Peychalogy Monorgepha, 1925, 2, No. 9.

Shor, Ro E. Hypnosis and the concept of the gerorelled realltyorfontation. American Journgl of Porohothergory, 1959. 13. 582-602.

Shor, R. B. The three factor theory of hypnoels as applied to the book reeding fantasy and to the concept of suggestion. International Joumal of Gilnteal and Bxperimentel Hrpnosis. $1970,18,89-98$.

Shor, R.E., Orne, M.T., \& O'Connell, D.N. Velidation and oroesvalidation of a seale of self-reported permonal experiences which predicts hypnotizability. Journgl of Porchology, $1962,52,55-75$.

Sanil, MeK. Suggeot1bility in achool childron. Pediatric Seminar, $1896,13,176-220$.

Sint th, T.L. The poychology of day droans. sertagn Jourpal of Pexchology, 1904, 15, 465-488.

Spanos, N.P. Goul-direted fantasy and the performance of hypnotic test suggestions. Parohiatry, 1971, $34,86-96$.

Spenos, N.P. Hypnosis, A sociological and phonomonological porspeotive. Dootoral dissertation, Boston Univeralty, 1973. Spanos, N.P., Barber, T.X. Cognitive setivity during "hypnotio" 
suegest1bilityi Goal=directed fantesy and the experlence of nonvolition. Joumal of Porsonallty, 1972, 4h, 510-524. Spanos, N.P. \& Barber, T.X. Toward a convergence in hypnoals rosearch, American Purohologlat, 1974, 29, 500-511.

Spanos, N.P., Barber, T.X., \& Lang, G. Bffects of hypnotic lnduotion, suegestions of analgesia, and demands for honesty on subjective roporte of pein. In H. London \& R. B. Hisbett (BAs.). Thouxht and foeling Cognitive al teration of feallng atates. Chlcagor Aldine, in press.

Spanos, N.P., Han, M.L. Cognitivo activity in response to hypnotic susesstion, Goal-directed fantasy and soloctive annesia. American Journel of Clinteal Hypnosis. $1973,25,191-198$. Spanos, N.P., Hae, M. H. Involvenent in Iragintng and the "hypnotio dream." Medfield, Mass., Modf1eld Foundation, 1974. (M1meo) Spanos, N.P., Haw, M.W., \& Barbor, T.X. Suggested ("hypnotic") visul hallucinations, Bxperinentel and phonomonological deta. Journgl of Abmorang Payahology, 1973, 81, 96-106. Spanos, N.P., Horton, C., \& Cheves, J.F. The effocts of tro cognitive strategles on pain throshold. Journal of Aboornel Peycholozy, in pross. Spanos, N.P., \& MaPeake, J.D. Involvenent In overyday Inaginative activities, attitudes towan hypnosis and hypnotic suggestiblity, Joumal of Persopal1ty and Sociol Perchology. in prass. 
Spanos, N.P., Splilane, J., t MaPeake, J.D. Ganl-directed fantasy and rosponse to suggestion in hypnotic and task-not1rated subjects. Medfleld, Mass.: Medfleld Foundation, 1974. Spanos, K.P., Valols, R., Han, M.H., \& Ham, M.L. Suggostiulity and Vividness and control of 1magory. Internat1onal Journal of Ginlogl and Bxperimental Hronosis, 1973, 27, 305-311.

Stukat, K.G. Suggest1 bilitr A factorlal and experimentel analysie. Stockholn, Alngrist H1keell, 1958.

Sutaliffe, J.P., Pexy, C.H., \& Sheohan, P.H. Relation of some aspects of Inegery and fantegy to hypnot1c suscept1bility. Journal of Abnomal Parchologx, 1970, 26, 279-287.

Tellegen, A., Atkinson, G.A. Openness to abeorbing and celfalterlng expertences, a tratt rolated to hypnot1c suscept1bilty. Journal of Abnomal Paychology, 1974, 83, 268-277. Wachtel, P.L. Hanting nothing and getting nothing: on negative results in hypnosis resesrch. Aporican Joumal of Alinical Hxpnos18, 1969. 11, 209-220.

Yarrow, M. H. The measuroment of chlldron's att1tudes and values. In P.H. Mussen (Fd.), Bandbook of resesrch gethods in ohl1d develophent, Now Yoxk, W1loy, 1960. 